\title{
The limits to collaboration across four of the most innovative UK industries
}

\section{Article}

Accepted Version

Audretsch, D. B. and Belitski, M. (2019) The limits to collaboration across four of the most innovative UK industries. British Journal of Management, 00. pp. 1-26. ISSN 1467-8551 doi: https://doi.org/10.1111/1467-8551.12353 Available at https://centaur.reading.ac.uk/84262/

It is advisable to refer to the publisher's version if you intend to cite from the work. See Guidance on citing.

To link to this article DOI: http://dx.doi.org/10.1111/1467-8551.12353

Publisher: Wiley

All outputs in CentAUR are protected by Intellectual Property Rights law, including copyright law. Copyright and IPR is retained by the creators or other copyright holders. Terms and conditions for use of this material are defined in the End User Agreement.

\section{www.reading.ac.uk/centaur}

\section{CentAUR}

Central Archive at the University of Reading

Reading's research outputs online 


\title{
The Limits to Collaboration Across Four of the Most Innovative UK Industries ${ }^{1}$
}

\begin{abstract}
This study demonstrates the importance and limits to external knowledge collaboration across different geographical dimensions and the most innovative UK industries (knowledge intensive business services (KIBS); high-tech manufacturing; Information and Communication Technologies (ICT); creative industries). Traditionally this issue has presented a challenge for the geography of innovation, external knowledge sourcing and open innovation literatures, in terms of firstly identifying the phenomenon and secondly in measuring it.

We propose and estimate a structural model that estimates the knowledge production function with innovation inputs and outputs at the firm level. Our sample includes 19,510 observations and 17,859 firms mainly from the UK Innovation survey and Business registry. We demonstrate that external collaboration may bestow a significant advantage for innovation developed by the firm and in collaboration with other businesses, but there are limits to collaboration. They are likely to be better offset by firms in knowledge intense sectors (KIS), while they remain consistent across collaboration with partners across four geographical regions. Our findings call for further research on innovation and revision of national and regional innovation policies.
\end{abstract}

\section{Introduction}

The innovation process involves a resource intensive search to find new combinations of commercially exploitable new technology and knowledge (Nelson and Winter, 1982; Stuart and Podolny, 1996; Hargadon and Sutton, 1997; Colombo et al., 2016; Laursen and Salter, 2006; Laursen, 2012). This requires organizations to create knowledge within a firm as well as source knowledge from external collaborators (Shan et al., 1994; Rosenkopf and Nerkar, 2001; Colombo et al., 2011). The joint use of the internal and external knowledge to accelerate firm's innovation has become a major foundation of "open innovation" concept (Chesbrough, 2006).

While the traditional innovation collaboration models are becoming more open (von Hippel, 2005; Chesbrough et al., 2006; Aldieri and Cincera, 2009; Borgers, 2011; West and Borgers, 2014; Choi and Contractor, 2017), the theoretical and empirical emphasis has increasingly moved towards the assumption on both the benefits and costs of external collaboration (Teece, 1986, 2000; Grindley and Teece, 1997; Veugelers, 1997, 1998; Cassiman

\footnotetext{
${ }^{1}$ The use of these data does not imply the endorsement of the data owner or the UK Data Service at the UK Data Archive in relation to the interpretation or analysis of the data. This work uses research datasets which may not exactly reproduce National Statistics aggregates.
} 
and Veugelers, 2002; Driffield et al., 2010, 2014; Colombo et al., 2016). Although external collaborations can help partners to co-create new products, managing external collaborations, facilitating knowledge transfer and offsetting potential costs of collaboration is not simple, as a firm may have to adopt a variety of external collaboration practices (Heiman and Nickerson, 2004). This includes the enhancement of internal knowledge base (e.g. investment in research and development (R\&D), hiring highly-skilled employees, training, etc.) which increase firm's competitive advantage by accumulating and integrating both internal and external knowledge (Helfat and Martin, 2015). An increase in economically valuable knowledge will challenge firm's appropriation and legal protection mechanisms, may result in an increase transaction costs and risk of uncontrolled knowledge flows to third parties (Ceccagnoli, 2009; Veugelers and Schneider, 2018). This suggests that investment in internal knowledge base along with an enhancement of external collaboration intensity may become a fundamental dilemma in the innovation management (von Hippel, 1994; Faems et al. 2005).

The rationale is as follows. Getting the knowledge from the external collaborators is only half the challenge, the other half is to exploit knowledge inflows and leverage knowledge outflows (West and Bogers, 2014), where the proprietary model frequently broke down (Chesbrough and Rosenbloom, 2002).

Despite the theoretical underpinning and importance of external collaboration in open innovation management literatures (Heiman and Nickerson, 2004; West and Bogers, 2014; West et al. 2014), relatively little theoretical and empirical research is available on the relationship between external knowledge collaboration and new product development, which is either developed within a firm (enterprise group) or co-created with other business partners.

Building on the extent literature on open innovation (Cassiman and Veugelers, 2002; Colombo et al. 2016), knowledge spillovers (Marshall, 1920; Audretsch and Feldman, 1996), innovation collaboration (Faems et al. 2005; Laursen and Salter, 2014; Beck and Schenker- 
Wicki, 2014) we discuss the potential limits to external collaboration and evaluate the direct and indirect effect of knowledge collaboration on firm's innovation developed by the firm and in collaboration with other businesses.

By employing both industrial and geographical perspectives (Boschma and Frenken, 2010; Kang and Park, 2012; Rodríguez et al., 2018) to external knowledge collaboration, this study estimates a knowledge production function (Pakes and Griliches, 1984; Crépon et al. 1998) for a sample of 17,859 firms (19,510 obs.) across the most innovative UK sectors (KIBS, high-tech manufacturing, ICT, creative sector) and across four geographical dimensions of collaboration (regionally, nationally, Europe and other world). In addition we control for selection bias (Dustmann and Rochina-Barrachina, 2007) and develop a model, which distinguishes between the benefits and costs of external knowledge collaboration for firm's innovation.

In doing so we aim to advance the theory and practice of external knowledge sourcing and open innovation (Dahlander and Gann, 2010) on how best to manage the firm's openness and enhance the internal knowledge base to the extent to which firm's innovation is facilitated. We also extend prior literature, which focused on knowledge sharing and expropriation in external innovation collaborations (Cassiman and Veugelers, 2002; Heiman and Nickerson, 2004) as well as on the dynamics of breadth in external innovation collaboration (Love et al. 2014; Chapman et al. 2018).

There are several important findings in this paper. Firstly, firms which develop innovation internally and in collaboration with other businesses will benefit from external knowledge collaboration. Secondly, a joint increase in external collaboration intensity and firm's internal knowledge base leads to a diminishing returns to knowledge collaboration also known as "the limits to collaboration". Thirdly, firms in knowledge intense sectors (KIS) are likely to be better integrate the external and internal knowledge into innovation activities, 
offsetting the limits to collaboration. Finally, our results highlight that limits to collaboration are consistent across four geographical dimensions of collaboration (regional, national, Europe, world). This study informs policymakers who are interested in stimulating firm's knowledge collaboration on a more comprehensive understanding of collaboration costs and benefits. This may lead to possible revisions in innovation and industrial policies as well as to revision in legal R\&D agreements between collaborators nationally and internationally.

Our findings call for more selectivity over the R\&D collaboration support for innovative firms (Beck and Schenker-Wicki, 2014; Hottenrott et al., 2017) as this may increase the pressure on firms to integrate internal and external resources at a high pace, increasing adjustment and valuation costs.

The next section sets out the hypotheses. Section 3 introduces the data and sample, while Section 4 introduces the methodology. Section 5 presents the results, while Section 6 discusses robustness checks. Section 7 concludes with major contributions, limitations, policy implications and future research.

\section{Theoretical framework}

The extent literature on knowledge collaboration and open innovation (Chesbrough, 2003, 2006; Laursen and Salter, 2014; Cassiman and Valentini, 2016) suggests that firms use external partners to exploit market opportunities, co-create new knowledge and commercialise it (Dyer and Singh, 1998; Ahuja, 2000; Belderbos et al., 2004; Cassiman and Veugelers, 2006).

Theoretically, external knowledge sourcing is grounded in a knowledge-based view (KBV) of the firm (Kogut and Zander, 1992; Grant, 1996), where knowledge becomes the key competitive resource (Penrose, 1959). Firms treat knowledge as the principal strategic resource, which is difficult to acquire freely in markets (Barney et al. 2001), rather than through 
inter-organisational (Fleming and Sorenson, 2004; Faems et al. 2005; Colombo et al. 2011) and R\&D collaborations (Bogers, 2011; Chapman et al. 2018).

The benefit from external collaboration for firm's innovation has been illustrated by empirical and theoretical works (Hagedoorn, 1993; Powell et al. 1996; Beers and Zand, 2014).

First, external knowledge collaboration allows for the inflow of resources required to exploit the market opportunities which may not exist within the firm, but across numerous collaboration partners (Laursen, 2012; Lakhani et al. 2013). Regarding knowledge inflows, we assume that a firm treats knowledge inflows positively.

Second, it enables access to inter-organisational knowledge (Faems et al. 2005) to facilitate their innovation search and performance (Beck and Schenker-Wicki, 2014; Roper et al., 2017).

Third, it helps to distribute the costs of innovation between partners (Veugelers, 1997, 1998) and to reduce the product development stage (Hagedoorn, 1993)

Fourth, according to the technology-based view, external knowledge collaboration is a core strategy for exploiting a firm's technology base as firms have to externalize their technology sourcing (Granstrand, 2000). The locus of firm's competitiveness shifts from firms to collaborators (Huang et al. 2015).

Fifth, firms collaborate when they cannot appropriate spillovers of their research (Ouchi and Bolton, 1988) or in markets that are uncertain and risky for a firm to go alone (West and Gallagher, 2006).

Finally, it is the increasing complexity of knowledge, customers and markets, which demands more and different kinds of collaboration (Brandenburger and Nalebuff, 1996; Bogers, 2011) to innovate in different markets (Teece, 1998; 2000; Narula and Duysters, 2004). We hypothesize:

H1: External knowledge collaboration positively affects firm's innovation. 
Prior research on open innovation assumes that external innovation collaboration increases the likelihood of complementarities between in-house knowledge creation and external knowledge embedded in partners (Cassiman and Veugelers, 2006; Beers and Zand, 2014). Complementarities and successful absorption of knowledge from external sources is likely to facilitate firm productivity and innovation (Nelson and Winter, 1982; Cohen and Levinthal, 1989; Cassiman and Valentini, 2016).

The resource-based view of a firm also suggests, that knowledge collaborations are established to develop a firm's dynamic capabilities and thus enhance its competitive advantage by accumulating and exploiting both internal and external resources (Teece, 1986) to successfully generate innovations (Lee and Wong, 2009; Santamaria et al. 2009; Escribano, Fosfuri and Tribó, 2009).

Although, investment in internal knowledge, while enhancing and diversifying external collaboration will add to cognitive, organizational and transaction costs (Cassiman and Valentini, 2016), prior research demonstrated, that firms gain from complementary knowledge, for example when co-location in industrial clusters to exploit knowledge collaboration and spillovers (Marshall, 1920; Audretsch and Feldman, 1996). External collaboration prevents firms from the "lock-in" risks and homogeneous knowledge (Balland et al. 2015). Investing in internal innovation and collaborating on "both sides of the R\&D market" (Chesbrough and Euchner, 2011: 14) is crucial and firms should be both active sellers and buyers of knowledge. In a dynamic organizational setting, then, one can expect as a firm increases collaboration in one relation (product), but it may look for ways to decrease collaboration in other relations (products), e.g. by establishing completely new collaboration to bestow knowledge commercialization (Cassiman and Veugelers, 2002), 
In practice, open innovation literature also demonstrated that the integration of internal and external resources entails five challenges, which increase the cost of collaboration and may limit marginal returns from collaboration, creating a certain limit.

Firstly, firms need a wide range of approaches to maximize the returns to external collaboration and simultaneous investment in R\&D, skills and competences, including intellectual property (IP) (maximization challenge). With a joint increase in knowledge investment in-house and collaboration intensity it is likely that knowledge appropriation issues arise to prevent the dispersion of $\mathrm{R} \& \mathrm{D}$ efforts across various collaborators, adding to innovation costs (Cassiman and Veugelers, 2002; West, 2003).

Secondly, firm should be able to integrate external and internal knowledge as well as continuously incorporate the relevant external knowledge into firm's innovation activities. This requires investment in absorptive capacity (Jansen et al. 2005), highly-skilled labour, new methods and ways to organize external collaboration to incorporate external knowledge (incorporation challenge). External knowledge often felt by firm's scientists as an implicit “indictment" of its own knowledge (Veugelers, 1997).

Thirdly, before incorporation into firm's innovation, valuation of external knowledge is an important issue (Granstrand, 2000) which may increase transaction costs, because of the difficult negotiations between collaborators (West and Gallagher, 2006). Partners are often reluctant to disclose sensitive tacit information about products and services (Arrow, 1962) (valuation challenge). Knowledge disclosure becomes an important issue when collaboration intensity grows. The challenge increases when a collaboration portfolio includes many partners (Choi and Contractor, 2017).

Fourthly, the cost of external collaboration (Gans and Stern, 2003; Chesbrough, 2006) includes the possible unintended knowledge outflows to rivals (Grindley and Teece, 1997; Cassiman and Veugelers, 2002, 2006; Iammarino and McCann, 2006; Laursen and Salter, 
2014) (knowledge appropriation challenge). Preventing it would require a cost of monitoring which leads to challenges in profit maximization and appropriability (Grindley and Teece, 1997; Laursen and Salter, 2005, 2014). The evidence was found in industries where knowledge creation is central activity (Hagedoorn, 1993; Powell et al. 1996; Almeida and Kogut, 1999; Kang and Park, 2012). Thus, a firm should be prepared and motivated to invest in internal R\&D as well as develop appropriation mechanisms to manage knowledge flows between collaborators (motivation challenge) (West et al., 2014; Hottenrott and Lopes-Bento, 2014). Above challenges are at the heart of the open innovation 'paradox', which means that internal innovation and external collaboration may function as two substitutive innovation choices (Faems et al. 2005; West and Gallangher, 2006).

We hypothesize:

H2: A joint increase in internal knowledge base and external collaboration intensity limits firm's innovation (the limits to collaboration).

Although investment in internal innovation and its integration with external knowledge increases risks and costs for a firm compared to others who do not invest in knowledge collaboration and integration, this does not mean that internal innovation and co-creation of products in collaboration is a dichotomous choice. In particular, most competitive firms in KIS will pursue internal innovation and collaboration as a form of competitive advantage. Although internal innovation and collaboration may be two substitute choices (Faems et al. 2005; Cassiman and Valentini, 2016), afterall internal innovation may increase returns to external innovation though absorptive capacity and vice versa, increasing commercialization of new products. This bring us to the next question. Will all industries be equally affected by the limits to collaboration? Not necessarily. In the KIS, external collaboration is strongly related to R\&D partnering with benefits of new product development accruing to both parties, whereas in sectors with a paucity of knowledge (e.g. medium and low-tech sectors) a dominant feature of 
partnering is market access (Hagedoorn, 1993). Due to the considerable strategic interdependence of firms in KIS and the complexity of product development, external innovation collaboration is more likely to occur, while also the risks of such collaboration are higher (Hagedoorn, 1993). Firms in KIS are aware of it and will undertake strategic (Hall et al. 2013, 2014) and legal knowledge protection measures, including sharing the IP rights, licencing and other form of IP collaboration, contracts (Megantz, 1996; Bogers, 2011; Hottenrott et al. 2017) to minimize those risks.

In particular, KIS firms will aim to enforce appropriability mechanisms, including patents, registration of designs, secrecy, package complexity to offset the potential limits to external collaboration. We hypothesize:

H3: Firms in the knowledge-intense sectors (KIBS, ICT, high-tech manufacturing and creative) will offset the limits to collaboration for firm's innovation.

The innovation collaboration literature (Baum et al., 2000; Rogers, 2004; Heiman and Nickerson, 2004; Love et al. 2014), often describes the knowledge transfer between partners as the adoption of practices, routines and culture, such as co-location, that facilitate knowledge collaboration (von Hippel, 1994) and knowledge spillovers (Marshall, 1920; Audretsch and Feldman, 1996). The empirical evidence is mainly based in the knowledge spillovers literature (Feldman and Audretsch, 1999; Audretsch et al. 2015).

Despite the benefits of co-location and knowledge localisation (Maskell, 2001), the extent of regional collaboration is likely to be limited because the knowledge may suffer from "the lock-in effect" (Boschma, 2005), with very little novel knowledge to offer to partners. In order to find new combinations of commercially exploitable knowledge (Stuart and Podolny, 1996; Hargadon and Sutton, 1997; Rosenkopf and Nerkar, 2001; Laursen, 2012) firms will 
collaborate across regions and national borders (Lahiri, 2010; Hottenrott and Lopes-Bento, 2014; Delgado-Márquez et al. 2017).

Although such outcomes are likely to be most diverse internationally, this form of collaboration requires more effective protection of knowledge such as IP, licensing, knowledge pooling when entering markets, enforcing contracts and other (maximization challenge). While explicit knowledge may be legally protected, much of tacit knowledge remains unprotected and thus is subject to potential exploitation by partners (Hall et al. 2014). It is plausible to assume that legal protection channels which could minimize the risks of collaboration, including unintended knowledge outflows, information disclosure and market risks and uncertainty (West and Gallagher, 2006) are limited once partners go international and deal with different institutional and cultural contexts (Autio et al. 2014, 2017).

Firms that collaborate internationally will need to invest more in absorptive capacity to integrate external collaboration knowledge (incorporation challenge). Unlike collaboration with international partners, regional and national boundaries offers R\&D collaboration agreements, which can be easily enforced and monitored. The higher benefits of collaboration with international partners could be easily dissipated if collaborative trust between partners is not established and disclosure of tacit knowledge cannot be prevented (Laursen and Salter, 2005).

There is a significant motivation challenge that increases external collaboration costs internationally. Firstly, on the supply side these are significant institutional differences between countries (Autio et al. 2014; Audretsch et al., 2018; Cumming et al., 2018), including rules enforcement, procedures and costs of registering a firm, market entry, taxes, tracking information flows. Secondly, on the demand side there is higher uncertainty and lower transparency in market operations between external partners and their customers, when collaborating internationally. 
Finally, firms may face liabilities from increased coordination and management costs internationally due to international diversity of regulations, cultures and mode of market entry (Zahra et al. 2000; Autio et al. 2014). Liabilities are also related to the newness of regulations and products, as well as the establishment of expensive internal management systems and networks, increasing collaboration costs (Lu and Beamish, 2004). We hypothesize:

H4: Firms that engage in collaboration with international partners will experience higher limits to collaboration for firm's innovation.

\section{Methodology and data}

\subsection{Data}

We test our hypotheses using three datasets (Business Registry, BSD), Business Expenditure in Research and Development (BERD), the UK Innovation Survey (UKIS) and six cross-sectional surveys with a panel element over 2002-2014. First, we collected and matched six consecutive UKIS waves: UKIS 4 2002-04, UKIS 5 2004-06, UKIS 6 2006-08, UKIS 7 2008-10, UKIS 8 2010-12 and UKIS 9 2012-14. Each wave was conducted every second year by the Office of National Statistics (ONS) in the UK.

Second, we used BSD and BERD data for the years 2002, 2004, 2006, 2008, 2010 and 2012. The data were matched to a correspondent UKIS survey wave for the initial year of the UKIS period. Firm age and ownership, employment, industry and firm size were matched from BSD. BERD collects data for in-house and bought-out $R \& D$, as well as the number of researchers with university degrees and above employed by the firm. The UKIS includes direct measures of innovation inputs and outputs, influencing barriers to innovation, measurements on human capital, partner types, training activity, partner locations, collaboration networks and other information related to our hypotheses. 
Although there are six surveys covering 10 years, we work with a sample of 19,510 observations with 17,859 firms available with non-missing values for innovation outputs and our main explanatory and control variable. There is a small panel element of 1,651 firms in a sample which was observed at least twice over 2002-2014. To be included in a sample, all questions related to the variables of interest needed to be completed with no missing values. For the list of variables included in this study and a sample size, please refer to Table 1 and their correlations (Table 2).

\section{TABLE 1 ABOUT HERE}

TABLE 2 ABOUT HERE

\subsection{Sample description}

Our sample includes four major innovative industries: high-tech manufacturing, ICT, KIBS, creative and the rest (other industries). The creative sector constitutes only of $4.4 \%$ of the sample, followed by ICT (7.3\%) and KIBS (10.5\%). High-tech manufacturing accounts for the highest share, with $11.6 \%$ of the observations (Table 3A). Other sectors represent $66.3 \%$ of the sample.

The left side of Tables 3A-3C shows the distribution of firms in the estimated sample, while the right side indicates the distribution of firms by industry, region and size across the population sample (this sample is original, and includes missing values on the variables of interest). The distribution of firms across estimated and population samples with regards to industries, regions and size remains stable over 2002-2014 (Tables 3A-3C). This is important as it enables us to generalize the results of our estimates to a larger sample. We observe a significant increase in non-reporting on questions of product and process innovation starting from UKIS 2010-2012 as compared to previous years. 


\section{TABLE 3 ABOUT HERE}

Table 4 shows the degree of collaboration with external partners across different geographic boundaries for firms in four major sectors (high-tech manufacturing, ICT, KIBS and the creative sector).

\section{TABLE 4 ABOUT HERE}

\subsection{Variables.}

We use three different dependent variables to measure firm's innovation, which is to the best of our knowledge are novel to external collaboration and firm's innovation research literature. Our first dependent variable equals to one if new to market goods and services were developed mainly by the business or enterprise group, zero otherwise. Our second dependent variable equals to one if new to market goods and services were developed mainly in collaboration with other businesses Our third dependent variable which was used for robustness check is the total sales of new-to-market products (in thousand pound sterling) taken in logarithms. It is calculated by multiplying total sales by the share of sales associated with new to market products. All three measures of firm innovation performance were taken from UKIS and their use is consistent with previous studies analysing firm innovation (Santamaría et al. 2009; Leiponen, 2005; Roper et al., 2008; Leiponen and Helfat, 2010), and within the UK Innovation surveys (Laursen and Salter, 2006, 2014; Frenz and Ietto-Gillies, 2009; Giovannetti and Piga, 2017).

We use two groups of observed explanatory variables. First group includes four variables describing knowledge collaboration with regional, national, European and international partners. These are continuous variable bounded between zero (if firm has zero collaboration 
partners within a specific region) to a maximum of six types of external collaboration partners (suppliers, customers, competitors, consultants and commercial labs, universities, governments) within each geographical dimension (Cassiman and Veugelers, 2002; Faems et al. 2005; Boschma and Frenken, 2010; Love et al. 2014). Second group includes R\&D intensity ( $R \& D$ expenditure to total sales) and the proportion of employees that hold a BA/BSc degree or higher qualification in science and engineering (scientists) (Cohen and Levinthal, 1989; Veugelers, 1997, 1998; Veugelers and Schneider, 2018). Both R\&D intensity and share of scientists were used to measure the investment in internal knowledge base as well as to illustrate firm's readiness to collaborate with external partners (Grant, 1996; West and Gallagher, 2006).

\section{Methodology}

\subsection{Sample selection}

In many problems of applied econometrics and management, the equation of interest is only defined for a subset of firms from the overall population, while the parameters of interest refer to the whole population (Dustmann and Rochina-Barrachina, 2007). In our sample the dependent variable can only be measured when the firm innovates. Out of 89,518 observations collected by the UKIS during 2002-2014, only 49.0 percent of observations are available for product innovation created in-house, 47.7 percent of observations - for innovation with other businesses and 37.9 percent of new to market product sales. Each round of UKIS is collected as a stratified sample (ONS, 2017), of a pull of firms by industry, region and size. A straightforward regression analysis may lead to inconsistent parameter estimates. This problem is well known as sample selection bias, while a Heckman estimator is available to correct for this (Heckman, 1979). If the selection process is time constant, panel estimators are able to 
resolve this problem, however in the unbalanced panel as ours this may not be the case. We apply the selection correction of the data on UK innovation survey 2002-2014.

Heckman (1979) procedure is used to test for the existence of selection bias using all available $n$ observations, estimate the probit model of $S_{i}$ on $Z_{i}$ and obtain the estimates $\widehat{\gamma_{h}} . S_{i}$ is a selection indicator for each firm i by $\mathrm{S}_{\mathrm{i}}$ we observe $\left(y_{i}, x_{i}\right), \mathrm{S}_{\mathrm{i}}=0$ otherwise. $\mathrm{S}_{\mathrm{i}}$ indicates we will use the observation in our analysis; $S_{i}=0$ means the observation will not be used. Given missing and unreported values of innovation outputs we use less than $\mathrm{n}$ in our sample, say $\mathrm{n}_{\mathrm{i}}$. In the selection equation of the Heckman (1979) procedure, our dependent variables $y_{i}$ are binary, equal one if innovation was reported by a firm (i) (in-house, co-creation or new product to market sales), zero otherwise. We compute the inverse Mill's ratio $\widehat{\lambda}_{l}=\lambda(z, \hat{\gamma})$ for each i. Using the selected sample, that is, the observations for which $S_{i}=1$ we run the regression of

$$
y_{i} \text { on } x_{i} \text { and } \hat{\lambda}_{i}
$$

The equation provides a simple test of selection bias. We use the usual t-statistics on $\hat{\lambda}_{i}$ as a test of null hypothesis: $\rho=0$. Under null hypothesis, there is no sample selection problem (Wooldridge, 2009: 610). In addition to $x_{i}$, we used three variables in the selection equation such as number of active plant units, in logs, factors constraining innovation (finance availability) and regulatory requirements (see Table 1). These variables are associated with propensity to innovate. Table A2 contains the results from the Probit (Tobit) and Heckman regressions for three innovation outputs. Standard errors reported for the Heckman results are Probit standard errors from regression (1). There is no evidence of a sample selection problem in estimating the innovation output function. The coefficient $\hat{\lambda}_{i}$ has a very small t-statistics (1.23), so we fail to reject the null: $\rho=0$. Just as importantly, there are no practically large differences in the estimated slope coefficients in Table A2. If there is no evidence of a sample selection, there is no reason to continue with correction for selection bias. 
4.2. Model specification: a two-stage knowledge production function

First stage estimation

Firms decide whether to source knowledge strategically, and firms with high levels of innovation performance may be more likely to source knowledge externally. This raises a possible endogeneity issue. In order to analyse the relationship between external knowledge collaboration and innovation performance at the firm level, we estimate a knowledge production function (Pakes and Griliches, 1984; Crépon et al. 1998) and correct for potential endogeneity. The IV estimator is obtained in two stages. The first stage concerns external innovation collaboration (collaboration intensity) (Leiponen and Helfat, 2010) when firms decide if or not to collaborate and how many types of collaborative partners to choose (Santamaria et al. 2009; Frenz and Ietto-Gillies, 2009). External collaboration intensity is correlated with the error. To estimate the knowledge production function we consider a standard linear model with a dependent variable $y_{i}$ (firm's innovation) and an endogenous variable $\varphi_{i}$ (collaboration intensity):

$$
y_{i}=\beta_{0}+\beta_{i} x_{i}+\omega_{i} \varphi_{i}+u_{i}
$$

We can also call it structural equation to emphasize that we are interested in $\beta_{i}$ and that the equation to be measured as causal. Variables $x_{i}$ and $\varphi_{i}$ are explanatory variables of firm's innovation and $u_{i}$ is an error term. $x_{i}$ is exogenous and not correlated with $u_{i}$, while $\varphi_{i}$ is likely to be correlated with $u_{i}$ (Wooldridge, 2009: 517). $\varphi_{i}$ is external collaboration intensity measured as the number of partner types (collaboration portfolio) with whom firm collaborates on innovation (suppliers, clients, competitors, consultants, universities, government ( 0 - no collaborators , max. 6) (Beers and Zand, 2014; Choi and Contractor, 2017).

We will instrument $\varphi_{i}$ with two exogenous variables with an assumption $\varrho_{1}$ (business belongs to an enterprise group (alliance) which includes at least 2 independent business units) and $\varrho_{2}$ (business made major changes in introducing new methods of organizing external 
relationships with other external firms and public institutions), that do not appear in (2) and are uncorrelated with the error $u_{i}$ are known as exclusion restrictions. In the reduced form of equation $\varphi_{i}$ is estimated as:

$$
\varphi_{i}=\pi_{0}+\beta_{i} x_{i}+\pi_{1} \varrho_{1}+\pi_{2} \varrho_{2}+v_{i}
$$

where $E\left(v_{i}\right)=0, \operatorname{cov}\left(\varrho_{1}, v_{i}\right)=0, \operatorname{cov}\left(\varrho_{2}, v_{i}\right)=0$. For this IV not to be perfectly correlated with $\varrho_{1}$ we need $\pi_{2} \neq 0$ and not to be perfectly correlated with $\varrho_{2}$ we need $\pi_{1} \neq 0$. The identification requires that $\pi_{1} \neq 0$ and $\pi_{2} \neq 0$ or both (Wooldridge, 2009: 523).

Using panel data element and, due to the nature of the dependent variables from the UKIS we used four multivariate Tobit models to predict the collaboration intensity $\left(\widehat{\varphi}_{l}\right)$. The reason of utilising Tobit estimation is that a significant number of firms. which report no collaboration partner (Table 4), results of collaboration intensity variable to be double censored. In addition to $\varrho_{1}, \varrho_{2}$ which are exclusion restrictions, other explanatory exogenous variables $x_{i}$ are included as well as a set of time and legal status fixed effects. Regional dummies were not used, because our dependent variable $\varphi_{i}$ in model (3) is regional and national collaboration intensity, which is a linear combination of regional dummies. The results of the first stage IV estimation across four geographical dimensions are reported in Table A1 in the Appendix, including the post-estimation test (chi2) of a joint significance of chosen instruments. Table A1 (specifications 1-4) in the Appendix illustrates the evidence for the first condition being satisfied with the coefficients of the chosen instruments and significant and positively associated with endogenous variable $\varphi_{i}$, ceteris paribus. Firms that belong to an enterprise group $\left(\varrho_{1}\right)(\beta=0.13-0.20, \mathrm{p}<0.05)$ and firms that introduce new methods of organizing external relationships with other firms $\varrho_{2}(\beta=1.06-1.61, \mathrm{p}<0.001)$ will experience higher collaboration intensity $\varphi_{i}$. 
IV Probit (IV Tobit) first "purges" $\varphi_{i}$ of its correlation with $u_{i}$ before doing the Probit (Tobit) regression in (2). Table 5 and 6 report the second-stage IV estimation with $\widehat{\varphi}_{l}$ and $x_{i}$ as explanatory variables.

We estimated equation (2) using IV Probit model when a dependent variable is binary and IV Tobit model (Amemiya, 1984) when a dependent variable is new to market sales which is double censored, as firms can have none or all sales from new to the market products (Faems et al., 2005; Laursen and Salter, 2006).

We save $u_{i}$ to provide the evidence of the second condition for IV to hold: $\varrho_{1}$ and $\varrho_{2}$ to be uncorrelated with $u_{i} \operatorname{corr}\left(\varrho_{i}, u_{i}\right)=0$, any linear combination is also uncorrelated with $u_{i}$ (Wooldridge, 2009). We estimate equation (4), where the dependent variable is $u_{i}$ from equation (2) regressed on the chosen instruments $\left(\varrho_{1}, \varrho_{2}\right)$. Table A3 has three models with three dependent variables $u_{i}$ : product innovation in-house residuals (specifications 1-4), product innovation external residual (specifications 5-8), innovative sales, in logs residual (specification 9-12).

$$
u_{i}=\beta_{0}+\beta_{i} z_{i}+\rho_{1} \varrho_{1}+\rho_{2} \varrho_{2}+\epsilon_{i}
$$

where $u_{i}$ is error from equation (2). Variables $z_{i}$ are control variables such as regional, year and industry 2 digit SIC fixed effects, firm ownership status variable and $\epsilon_{i}$ is an error term. Coefficients $\rho_{1}$ and $\rho_{2}$ (Table A3) are not statistically significant and we conclude that across two innovation models and four geographical dimensions $\operatorname{corr}\left(\varrho_{i}, u_{i}\right)=0$, thus $\rho_{1}$ and $\rho_{2}$ are valid instruments for $\varphi_{i}$.

\section{Results}

5.1. External collaboration and innovation in firms 
We start by estimating equation (2) using IV probit across four KIS, other sectors and the overall estimation. Results are reported in Table 5 and illustrate the direct effect of knowledge collaboration on firm's own innovation (in-house).

\section{TABLE 5 ABOUT HERE}

Although the benefits from external collaboration are different across four KISs and other sectors, the coefficients of regional, national and European external collaboration intensity are consistently positive and significant. Firms in the high-tech manufacturing have almost no benefits from external knowledge collaboration, while the factors which drive firm's innovation are $R \& D$ intensity $(\beta=0.20, \mathrm{p}<0.01)$, exploration activity in new markets and products $(\beta=0.44, \mathrm{p}<0.01)$, investment in human capital $(\beta=0.15, \mathrm{p}<0.001)$ and export orientation $(\beta=0.88, p<0.01)$. Amongst KIS, firms in the ICT and KIBS sectors benefit most from external collaboration with major effect of collaboration with regional and national partners. Other factors which facilitate innovation in ICT are R\&D intensity $(\beta=0.23$, $\mathrm{p}<0.001)$, exploration activity $(\beta=0.25, \mathrm{p}<0.001)$, investment in human capital $(\beta=0.14$, $\mathrm{p}<0.001)$, and export orientation $(\beta=0.39, \mathrm{p}<0.001)$. For KIBS the most influential factors remain, $R \& D$ intensity $(\beta=0.31, p<0.001)$, exploration activity $(\beta=0.39, p<0.001)$, investment in human capital $(\beta=0.10, \mathrm{p}<0.001)$, export orientation $(\beta=0.45, \mathrm{p}<0.001)$, firm age $(\beta=-0.08$, $\mathrm{p}<0.001)$ and firm size $(\beta=0.28, \mathrm{p}<0.001)$. Creative sector benefits from collaboration with national partners most as well as investment in innovation are $R \& D$ intensity $(\beta=0.06, p<0.01)$, exploration activity $(\beta=0.53, \mathrm{p}<0.01)$, human capital $(\beta=0.07, \mathrm{p}<0.001)$ and export $(\beta=0.42$, $\mathrm{p}<0.01)$

Factors which impede innovation are lack of market knowledge and other factors equally negatively affected all KIS and non-KIS (other sectors). Interestingly, the "other sectors" (nonKIS), characterized by the paucity of knowledge have strong positive benefits from external 
knowledge collaboration in particular within national and regional partners. Firms in non-KIS are less likely to invest in internal knowledge find it economically viable to source knowledge from external partners. Our finding supports H1 (Chesbrough, 2006; Laursen and Salter, 2014).

\subsection{External collaboration and firm's innovation}

The results of IV probit estimation are in (Table 6, columns 1-8), while the results of IV Tobit are in (Table 6, columns 9-12).Table 6 (columns 1-4 and 9-12) illustrates the direct and indirect effects (interaction analysis) of external collaboration on firm's innovation developed by a firm, while Table 6 (columns 5-8) illustrates the direct and indirect effects (interaction analysis) for firm's innovation co-created with other businesses. Results overwhelmingly support $\mathrm{H} 1$ on the positive impact of external collaboration for new product creation by the firm and in collaboration with external partners. External collaboration facilitates new to market product sales. Collaboration with regional and national partners has higher impact on firm's innovation that external collaboration with Europeans and international partners (Table 6). von Hippel (1994) and Iammarino and McCann (2006) explain this phenomenon as a 'sticky' innovation process within particular regions. Although both the KISs and other sectors have positive returns to external collaboration on firm's innovation and across different geographical dimensions, non-KIS are likely to benefit more by collaboration (Figure 1).

\section{FIGURE 1 ABOUT HERE}

\subsection{The limits to collaboration}

To test our $\mathrm{H} 2$ we investigate the sign of the two-way interaction between internal knowledge investment (R\&D intensity and share of scientists) and external collaboration intensity across three equations. Although the direct effect of $R \& D$ and scientists (standardized) is positive and statistically significant (Chesbrough et al. 2006; Escribano et al. 
2009; Beers and Zand, 2014), the interaction (indirect) effect of R\&D intensity and collaboration intensity as well as share of scientists and collaboration intensity is negative (Veugelers et al. 1997; Cassiman and Veugelers, 2002). Although the coefficient is small, it is significant pointing on the existence of negative externalities of collaboration such as maximization challenges and transaction costs (Bogers et al. 2017). The results are consistent across three models. The negative sign of the interaction term demonstrates a decreasing pattern of returns to external collaboration. For example, an increase in one standard deviation of $R \& D$ intensity along with an increase in collaboration intensity by one unit (partner) is likely to decrease the likelihood of firm's innovation in-house on average by $(\beta=-0.03, p<0.05)$ when collaborating with regional partners, $(\beta=-0.05, \mathrm{p}<0.01)$ when collaborating with national partners, $(\beta=-0.04, p<0.01)$ when collaborating with European partners and $(\beta=-0.06, p<0.01)$ when collaborating with international partners (Table 6, spec. 1-4). For firms who co-create products with other businesses, an increase in one standard deviation of R\&D intensity along with increase in collaboration intensity by one unit (partner) is likely to decrease returns to cocreation between by 0.02 for European and international partners and 0.04 for national partners (Table 6, spec. 5-8). A decrease in firm's innovation when a firm jointly increases internal knowledge base and external collaboration intensity is termed "the limits to collaboration". Our robustness check of the limits to collaboration using IV Tobit estimation for new product sales supports H2 (Table 6, spec. 9-12).

The interaction results also support $\mathrm{H} 2$ (Table 6, spec. 1-8). An increase in one standard deviation of "scientists" along with an increase in collaboration intensity by one unit (partner) is likely to decrease the likelihood of firm's innovation in-house between 0.01 and 0.05 $(\mathrm{p}<0.01)$. No factors constraining collaboration with European and international external partners were found for in-house innovation (Table 6, spec. 1-4). It is likely that firms collaborate to a lesser extent with international partners while developing new products in- 
house or firms who collaborate internationally are better prepared to monitor the knowledge transfer (or both) (Veugelers et al. 1997)

Firms which co-create new product with other businesses are more likely to experience the limits to collaboration as we observe decreasing returns to knowledge collaboration by $(\beta=-$ 0.04, $\mathrm{p}<0.001)$ when collaborating with regional and European partners, by $(\beta=-0.06, \mathrm{p}<0.001)$ when collaborating with regional partners, by $(\beta=-0.05, \mathrm{p}<0.001)$ when collaborating with European partners and by $(\beta=-0.04, \mathrm{p}<0.001)$ when collaborating with national and international partners (Table 6, spec. 5-8). Robustness check for the "limits to collaboration" applied to new product to market sales (Table 6, spec. 9-12) also supports H2. Table 6 (spec. 9-12) illustrates a joint increase in one standard deviation of scientists' share and one collaboration partner decreases returns to regional collaboration for new product sales by 0.31 percent for regional collaboration, 0.17 percent for national collaboration, 0.21 percent for European and 0.25 percent for international collaborators supporting prior findings on knowledge integration (West and Gallagher, 2006; Bogers et al. 2017).

The fact that the limits to collaboration are consistent across external collaborations within all four geographical dimensions does not support H4. This is an interesting finding, as we evidence that co-location increases the likelihood of new product creation, while the distance to partner is not a boundary condition limiting collaboration.

5.4. Internal innovation and external collaboration: substitutes or compliments?

The essential premise of the limits to collaboration appears to be that combining internal and external sources of knowledge is costly and risky. This brings us to consideration that external sources and internal innovation may be substitutes and it needs to be unpicked further. Although both internal and external innovation is likely to facilitate the development and 
commercialization of new products (Chesbrough, 2003, 2006; West et al. 2014), their joint development is costly and when resources are limited, managers are likely to choose either of two strategies. Firms may rely on absorptive capacity to facilitate innovation.

In order to test this relationship we estimated equation (2) using internal collaboration (innovation was created in-house) and external collaboration (co-creation of innovation) as explanatory variables, interacting them with firm's absorptive capacity (Jansen et al. 2005) to demonstrate if afterall internal innovation may increase returns to external innovation though absorptive capacity and vice versa. Table A4 (spec. 1,4,7) in the Appendix reports the results of estimation with controls only. Table A4 (spec. 4-6) illustrates the effect of internal innovation on external collaboration and (Table A4, spec. 1-3) - the effect of external collaboration on internal innovation. We also examine the joint effect of external collaboration and internal innovation on new product sales interacting internal innovation and co-creation with absorptive capacity (proxied by scientists and R\&D intensity). Our results are intriguing. Table A4 (spec. 1-3) demonstrated that co-creating innovation decreases the likelihood of internal innovation by $44.4 \%$, while further investment in absorptive capacity accelerates the substitution effect (Cassiman and Valentini, 2016) both for scientists and R\&D intensity. Similarly, firms that invest in internal innovation are $48 \%$ less likely to co-create innovation with partners, with investment in absorptive capacity increases the substitution effect, both for scientists and R\&D intensity (Table A4, spec. 4-6). Although, the limits to collaboration will make a firm to choose between two strategies as the long-run cost of learning through absorptive capacity may be substantial (Cohen and Levinthal, 1989), internal innovation and co-creation of products positively affect new product sales (Table A4, spec. 7-9). We found that interaction coefficient of innovation and R\&D is not statistically significant, while the interaction coefficient between innovation and share of scientists is positive. The result demonstrated that capabilities and skills embodied in scientists 
are crucial for both internal innovation and co-creation with external partners to commercialize new products as a form absorptive capacity (Cohen and Levinthal, 1989). R\&D costs further limits assimilating and exploiting of innovation (in-house and co-creation). This is likely to be associated with the cost and maturity level of R\&D expenditure (Enkel, Bell and Hogenkamp, 2011), while human capital can be rapidly applied and integrated in innovation strategies.

\subsection{Industrial perspective to the limits to collaboration}

To test our H3 we investigate the sign of the three-way interaction between internal knowledge investment (R\&D intensity and share of scientists) and external collaboration intensity conditional on the industry where a firm is located ("KIS" vs. non-KIS sector). Our rationale comes from the a prior evidence that firms in KIS are likely to better monitor and appropriate intangible knowledge (Bogers, 2011; Bogers et al. 2017) than do firms in the other sectors. Results in Table 6 partially support H3 with KIS firms are able to offset the cost to collaboration associated with control over R\&D expenditure, however not the limits of collaboration which are associated with human capital management (share of scientists). Results of the estimation across three dependent variables are different. For example, KIS firms are more likely to leverage the limits to collaboration when creating products in with other businesses $(\beta=0.03-0.05, \mathrm{p}<0.01)$ (Table 6 , spec. 5-8), rather than doing it in-house $(\beta=0.01$, p>0.10) (Table 6, spec. 1-4). We also found that firms in KIS are able better offset a decrease in new product sales, while non-KIS are not (Table 6, spec. 9-12). The results of Tobit estimation can be interpreted directly with $0.27,0.46,0.47$ and 0.38 percent offsetting salesdrop in KISs while investing in R\&D and collaboration compared to non-KIS firms. The fact that firms in both KIS and non-KIS sectors who have higher share of scientists cannot offset the costs to collaboration is likely to be associated with more complex mechanisms and loopholes in labor market. Greater monitoring and instructing scientists employed by a firm, 
while those exploit various channels of collaboration and co-creation, knowledge transfer may be limited (Boardman and Ponomariov, 2009; Bradley et al. 2013) which may result in knowledge outflows.

Interesting finding relates to our control variables (Table 6). Firm size is an important predictor of innovation within a firm (enterprise group). Large firms and medium firms (are more likely than small firms to develop new products in-house, while both large and small firms with equal likelihood co-create new products (Baum et al. 2000). The exploration activity is positively associated with the likelihood of innovation and new product sales. Firms which report a high cost of innovation as an impediment are more likely to innovate in-house, than co-create new products. Firm age is negatively associated with new product developed by the firm and in collaboration with other businesses. More mature firms also experience lower new product sales, than do younger firms.

\section{Further robustness checks}

Firstly, the difficulties arise from the fact that the product innovation indicators and collaboration are defined over 3-year period. As a robustness check we estimated the equation (4) using lagged predicted values of collaboration for a small panel element of 1,651 firms observed at least twice over 2002-2014. Given the low volatility of external innovation collaboration over time, the results with signs and confidence intervals of the regression coefficients were similar to those reported in Tables 6.

Secondly, we included the associated longitudinal survey weights (ONS, 2017) in the estimation of (4) with the coefficients signs and significance remained unchanged.

Thirdly, we estimated (4) for each of three dependent variables, using a multilevel model, sometimes also called a hierarchical, random coefficient or mixed-effect model, as the data structure in the population is hierarchical (Goldstein, 2003; Gelman and Hill, 2006). Firms are 
hierarchically nested in a three-level model: six waves of the BSD-BERD-UKIS dataset; 12 UK regions and industris (Goldstein, 2003) ${ }^{2}$. The signs and the direction of the relationship and coefficients for explanatory variables reported in Table 6 were not statistically different.

\section{Discussion and Conclusion}

The measurement and management of the external knowledge collaboration for firm's innovation has long remained an open question in the external knowledge sourcing and open innovation literatures (Cassiman and Veugelers, 2002; Gans and Stern, 2003; West and Gallagher, 2006; Chesbrough, 2006; Bogers, 2011).

The purpose of this study was to understand and measure the effect of external collaboration as well as the limits to such collaboration for the most innovative UK firms. To accomplish this we applied both the industrial and geographical perspective within the evolving literature on open innovation (West, 2003; Chesbrough 2003, 2006; West and Gallagher, 2006; Colombo et al. 2011, 2016; Driffield et al., 2010, 2014; Love et al., 2014; Cassiman and Valentini, 2016).

We found strong evidence that the likelihood of firm's innovation developed by the firm and in collaboration with other businesses increases with external collaboration intensity. Firms who collaborate within close proximity will not experience higher innovation than firms collaborating with international partners, illustrating that limits to collaboration do not increase with the geographical proximity. . We also found that joint increase in collaboration intensity and absorptive capacity does not results in more benefits from external collaboration. On the contrary, there are limits to collaboration associated with maximization, incorporation, valuation and motivation challenges, preventing a continuous increase in innovation output.

\footnotetext{
${ }^{2}$ Estimates are available from authors upon request.
} 
Interestingly, firms in KIS are more likely to offset the limits to collaboration via control over R\&D intensity, rather than share of scientists they employ.

The geographical and industrial perspective to external collaboration enables us to distinguish three collaboration strategies, which could be applied by the most innovative firms to better offset the limits to collaboration. First, control and monitoring human capital when developing new to market product in-house (internal innovation). Second, prioritizing a certain type of collaboration partner to offset increase in transaction costs when a number of partners increases. Third, develop appropriation and coordination mechanisms to enhance the likelihood of new product creation (Choi and Contractor, 2017). This study makes the following contributions to the management of innovation, external knowledge sourcing and open innovation literature.

Firstly, we identify the industrial boundaries of the external knowledge collaboration, such as KISs in terms of their size and impact on firm innovation, when a new product is developed by the firm and in collaboration with other businesses. We emphasize the role of KIS firms who better offset the limits to collaboration compared to non-KIS firms.

Secondly, we identify the role of geographical dimension for external knowledge collaboration and demonstrate that returns to collaboration are consistent across different geographical dimensions.

In addition, the application of a structural model to innovation data on external knowledge collaboration may offer methodological cues for cross-sectional analysis with a small panel component as well as the issue of selection biases when dealing with innovation survey data.

Our results are in line with previous research (Chesbrough, 2003, 2006; Laursen and Salter, 2006; Leiponen and Helfat, 2010; Bogers, 2011; Bogers and Horst, 2014), suggesting that firms in the KIS and non-KIS need to be treated differently. . 
Finally, this study makes several key points to firm managers and policy-makers. Firstly, despite the importance of innovation openness (Love et al. 2014), there are the limits to external collaboration (Teece, 1986; Veugelers, 1997). The assumption that UK firms can linearly increase their innovation outputs while increasing collaboration intensity (partner portfolio) and investing in the knowledge base internally was not supported.

Secondly, while firms are likely to choose either internal innovation or external collaboration, the simultaneous engagement in internal innovation and co-creation with external partners provides extra gains in new product commercialization, with human capital playing a crucial role in facilitating innovation.

Thirdly, we suggest that KIS firms may benefit from an increased positive externalities and knowledge spillovers (Audretsch and Feldman, 1996).

One of the limitations of this study is that data was gathered using a survey that was not specifically designed to tests the limits to external collaboration. In the UKIS, firms are asked about their collaboration decisions along with the collaboration partner portfolio and the degree of collaboration, rather than the number of collaboration partners within each type, the level of connectedness (frequency of communication, intensity) and the length of such collaboration contacts. Another limitation is a reduction in observations in the final three waves of UKIS (2008-2014). It is likely that the global financial crises had an impact on the innovation and external collaboration behaviour of firms.

This study calls for future research on knowledge sourcing from external partners within and between industries as well as across different geographical proximities. Special focus should be on capturing the intensity of contacts when collaboration takes place between firms (organizational level) as well as between leading managers and scientists (individual level). Further information should be obtained on collaborative $R \& D$ and other knowledge transfer agreements between the recipient and distributor of knowledge. Finally, research is needed on 
innovation collaboration costs (beyond $\mathrm{R} \& \mathrm{D}$ expenditure) in the most innovative sectors. Future research on "other sectors", including emerging sectors as well as comparative studies using firm-level data across various spatial, technological, institutional, temporal, cultural and other proximities (Boschma, 2005). Subsequent research will need to embrace other forms of firm's innovation performance, including process innovation, organizational and management innovation, exploration activity and innovation search.

\section{References}

Ahuja, G. (2000) 'Collaboration networks, structural holes, and innovation: A longitudinal study,' Administrative science quarterly, 45(3), pp. 425-455.

Aldieri, L. and M. Cincera (2009). 'Geographic and technological R\&D spillovers within the triad: Micro evidence from US patents', The Journal of Technology Transfer, 34(2), pp. 196211.

Almeida, P. and B Kogut. (1999). 'Localization of knowledge and the mobility of engineers in regional networks', Management science, 45(7), pp. 905-917.

Arrow, K.J. (1962). 'Economic welfare and the allocation of resources for invention', in National Bureau of Economic Research (Ed.), The Rate and Direction of Inventive Activity: Economic and Social Factors, Princeton University Press, Princeton, NJ, pp. 609-625.

Amemiya, T. (1984). 'Tobit models: A survey', Journal of Econometrics, 24(1-2), pp. 3-61. Audretsch, D.B., and M.P. Feldman (1996). 'R\&D spillovers and the geography of innovation and production', The American economic review, 86(3), pp. 630-640.

Audretsch, D. B., M. Belitski, and S. Desai (2015). 'Entrepreneurship and economic development in cities', The Annals of Regional Science, 55(1), pp. 33-60.

Audretsch, D. B., M. Belitski and S. Desai (2018). 'National Business Regulations and City Entrepreneurship in Europe: A Multilevel Nested Analysis'. Entrepreneurship Theory and Practice, 1042258718774916.

Autio, E., M. Kenney, P. Mustar, D. Siegel and M. Wright (2014). 'Entrepreneurial innovation: The importance of context', Research Policy, 43(7), pp.1097-1108.

Autio, E, S. Nambisan, L Thomas and M. Wright (2017) 'Digital affordances, spatial affordances, and the genesis of entrepreneurial ecosystems'. Strategic Entrepreneurship Journal, 12(1), pp. 72-95.

Balland, P-A, R. Boschma and K. Frenken (2015). 'Proximity and innovation: From statics to dynamics'. Regional Studies, 49(6), pp. 907-920.

Barney, J., M. Wright and D.J. Ketchen (2001). 'The resource-based view of the firm: Ten years after 1991', Journal of Management, 27(6), 625-641.

Baum, J.A.C., T. Calabrese and B.S. Silverman (2000) 'Don't Go It Alone: Alliance Network Composition and Startups' Performance in Canadian Biotechnology,' Strategic Management Journal, 21(3), pp. 267-294.

Beck, M. and A. Schenker-Wicki (2014) 'Cooperating with external partners: the importance of diversity for innovation performance,' Eur. J. Int. Manag, 8, pp. 548-569.

Beers, C. and F. Zand (2014) 'R\&D cooperation, partner diversity, and innovation performance: an empirical analysis', Journal of Product Innovation Management, 31(2), pp. 292-312. 
Belderbos, R., M. Carree and B. Lokshin (2004). 'Cooperative R\&D and firm performance', Research policy, 33(10), pp.1477-1492.

Boardman, P. C. and Ponomariov, B. L. (2009). 'University researchers working with private companies', Technovation, 29(2), pp. 142-153.

Bogers, M. (2011). 'The open innovation paradox: knowledge sharing and protection in R\&D collaborations', European Journal of Innovation Management, 14(1), pp. 93-117.

Bogers, M. and Horst, W. (2014). 'Collaborative prototyping: Cross-fertilization of knowledge in prototype-driven problem solving', Journal of Product Innovation Management, 31(4), pp. 744-764.

Bogers, M., A. K. Zobel, A. Afuah, E. Almirall, S. Brunswicker, L. Dahlander ... and J. Hagedoorn (2017). 'The open innovation research landscape: Established perspectives and emerging themes across different levels of analysis'. Industry and Innovation, 24(1), pp. 840 .

Boschma, R. (2005). 'Proximity and innovation: a critical assessment', Regional studies, 39(1), pp. 61-74.

Boschma, R. and K. Frenken (2010). 'The spatial evolution of innovation networks. A proximity perspective'. The handbook of evolutionary economic geography, pp. 120-135.

Bradley, S. R., Hayter, C. S. and Link, A. N. (2013). 'Models and methods of university technology transfer', Foundations and Trends ${ }^{\circledR}$ in Entrepreneurship, 9(6), pp. 571-650.

Brandenburger, A.M. and K. Nalebuff, B.J. (1996). 'Co-opetition'. New York, NY:

Doubleday.

Cohen, W. M. and D.A. Levinthal (1989). 'Innovation and learning: the two faces of R\&D', The Economic Journal, 99(3), pp. 569-596.

Cassiman, B. and R. Veugelers (2002). 'R\&D cooperation and spillovers: some empirical evidence from Belgium'. American Economic Review, 92(4), pp. 1169-1184.

Cassiman B, and Veugelers R. (2006) 'In search of complementarity in innovation strategy: internal R\&D and external knowledge acquisition', Management Science, 52, pp. 68-82.

Cassiman, B. and G. Valentini (2016). Open innovation: are inbound and outbound knowledge flows really complementary? Strategic management Journal, 37, pp. 1034-1046.

Ceccagnoli, M. (2009). 'Appropriability, preemption, and firm performance', Strategic Management Journal, 30, pp. 81-98.

Chapman, G., A. Lucena and S. Afcha (2018) 'R\&D subsidies \& external collaborative breadth: Differential gains and the role of collaboration experience'. Research Policy, 47(3), pp. 623-636.

Chesbrough, H. and R.S. Rosenbloom (2002). 'The role of the business model in capturing value form innovation: evidence from Xerox corporation's technology spin-off companies', Industrial and Corporate Change, 11(3), pp. 529-555.

Chesbrough, H. (2003). Open Innovation. Harvard University Press: Cambridge, MA. Chesbrough, H. (2006). Open Innovation: The New Imperative for Creating and Profiting from Technology, Harvard Business Press: Boston, MA.

Chesbrough, H., Vanhaverbeke, W., West, J. (Eds.), (2006). Open Innovation: Researching a New Paradigm. Oxford University Press: Oxford.

Chesbrough, H., and J. Euchner (2011) 'The evolution of open innovation: an interview with Henry Chesbrough'. Research Technology Management 54(5), pp. 13-18.

Choi, J. and F.J. Contractor (2017). 'Improving the progress of research \& development (R\&D) projects by selecting an optimal alliance structure and partner type', British Journal of Management.

Colombo, M. G., K. Laursen, M. Magnusson and C. Rossi-Lamastra, C. (2011). 'Organizing inter-and intra-firm networks: what is the impact on innovation performance?' Industry and Innovation, 18(6), pp. 531-538. 
Colombo, M.G., D. Cumming, A. Mohammadi, C. Rossi-Lamastra and A. Wadhwa (2016). 'Open business models and venture capital finance', Industrial and Corporate Change, 25(2), pp. 353-370.

Crépon, B., E. Duguet and J. Mairesse (1998). 'Research, Innovation And Productivity An Econometric Analysis At The Firm Level,' Economics of Innovation and new Technology, 7(2), pp.115-158.

Cumming, D., A. P. Groh and S. Johan (2018). 'Same rules, different enforcement: Market abuse in Europe', Journal of International Financial Markets, Institutions and Money, 54, 130151.

Dahlander, L. and D.M. Gann (2010). 'How open is innovation?', Research Policy, 39(6), 699709.

Delgado-Márquez, B, N. Hurtado-Torres, L. Pedauga and E. Cordón-Pozo (2017). 'A network view of innovation performance for multinational corporation subsidiaries', Regional Studies, 30(2), pp. 103-121.

Driffield, N., J.H. Love and S. Menghinello (2010) 'The Multinational Enterprise as a Source of International knowledge flows: Direct evidence from Italy', Journal of International Business Studies, 41(2), pp. 350-359.

Driffield, N., J.H. Love, and Y. Yang. (2014) 'Technology sourcing and reverse productivity spillovers in the multinational enterprise: global or regional phenomenon?' British journal of management, $25, \mathrm{~S} 1$.

Dustmann, C., and Rochina-Barrachina, M. E. (2007). 'Selection correction in panel data models: An application to the estimation of females' wage equations'. The Econometrics Journal, 10(2), 263-293.

Escribano, A., A. Fosfuri and J. A. Tribó (2009). 'Managing external knowledge flows: The moderating role of absorptive capacity', Research policy, 38(1), pp. 96-105.

Enkel, E., J. Bell and H. Hogenkamp (2011). 'Open innovation maturity framework,' International Journal of Innovation Management, 15(06): pp. 1161-1189.

Faems, D., B. Van Looy and K. Debackere (2005). 'Interorganizational collaboration and innovation: Toward a portfolio approach,' Journal of product innovation management, 22(3), pp.238-250.

Feldman, M. and D.B. Audretsch (1999). 'Innovation in cities: science-based diversity, specialization and localized competition,' European Economic Review, 43, pp. 409-429.

Frenz, M., and G. Ietto-Gillies, (2009). 'The impact on innovation performance of different sources of knowledge: Evidence from the UK Community Innovation Survey', Research Policy, 38(7), pp. 1125-1135.

Fleming, L. and O. Sorenson (2004). 'Science as a map in technological search,' Strategic Management Journal, 25, pp. 909-928.

Fritsch, M., \& Mueller, P. (2008). The effect of new business formation on regional development over time: the case of Germany. Small Business Economics, 30(1), 15-29. Gans, J.S. and S. Stern, S. (2003) 'The product market and the market for 'ideas': commercialization strategies for technology entrepreneurs,' Research Policy, 32, pp. 333-350.

Granstrand, O. (2000). 'The Economics and Management of Intellectual Property: Towards Intellectual Capitalism'. Edward Elgar Publishing, Cheltenham.

Grant, R. M. (1996) 'Toward a knowledge-based theory of the firm,' Strategic Management Journal, 17(S2), 109-122.

Grindley, P.C. and D.J. Teece (1997). 'Managing intellectual capital: licensing and crosslicensing in semiconductors and electronics'. California Management Review, 39 (2), pp. 8 41.

Gelman, A. and Hill, J. (2006). Data analysis using regression and multilevel/hierarchical models. Cambridge University Press. 
Giovannetti, E. and C.A Piga (2017). 'The contrasting effects of active and passive cooperation on innovation and productivity: Evidence from British local innovation networks', International Journal of Production Economics, 187, pp.102-112.

Goldstein, H. (2003). Multilevel statistical models. Arnold: London, UK.

Hagedoorn, J. (1993). 'Understanding the rationale of strategic technology partnering: Interorganizational modes of cooperation and sectoral differences', Strategic management journal, 14(5), pp.371-385.

Hall, B., C. Helmers, M. Rogers, M. and V. Sena (2013). 'The importance (or not) of patents to UK firms,' Oxford Economic Papers, 65(3), pp.603-629.

Hall, B., C. Helmers, M. Rogers, M. and V. Sena (2014). 'The choice between formal and informal intellectual property: a review', Journal of Economic Literature, 52(2), pp.375-423.

Hargadon, A. and Sutton, R. (1997). 'Technology brokering and innovation in a product development firm,' Administrative Science Quarterly, 42, pp. 716-749.

Heckman, J. (1979). 'Sample selection bias as a specification error,' Econometrica, 47(1), pp. 153-161.

Heiman, B.A. and J.A. Nickerson (2004) 'Empirical Evidence regarding the Tension between Knowledge Sharing and Knowledge Expropriation in Collaborations,' Managerial and Decision Economics, 25, pp. 401-420.

Helfat, C. E. and J.A. Martin (2015). 'Dynamic managerial capabilities: Review and assessment of managerial impact on strategic change', Journal of Management, 41(5), pp. 1281-1312.

Hottenrott, H. and C. Lopes-Bento (2014). '(International) R\&D collaboration and SMEs: the effectiveness of targeted public R\&D support schemes,' Research Policy, 43, pp. 1055-1066. Huang, K. F., R. Dyerson, L. Y. Wu and G. Harindranath (2015). 'From temporary competitive advantage to sustainable competitive advantage', British Journal of Management, 26(4), pp. 617-636.

Iammarino, S. and P. McCann (2006). 'The structure and evolution of industrial clusters: Transactions, technology and knowledge spillovers', Research policy, 35(7), pp. 1018-1036.

Jansen, J.J.P., F.A.J. Van den Bosch and H.W. Volberda (2005). 'Managing potential and realized absorptive capacity: how do organizational antecedents matter?' Academy of Management Journal, 48, pp. 999-1015.

Kang, K.N. and H. Park (2012) 'Influence of government R\&D support and inter-firm collaborations on innovation in Korean biotechnology SMEs,' Technovation, 32, 68-78.

Kogut, B. and U. Zander (1992). 'Knowledge of the Firm, Combinative Capabilities, and the Replication of Technology,' Organization Science, 3(3), pp. 383-397.

Lahiri, N. (2010). 'Geographic distribution of R\&D activity: how does it affect innovation quality?', Academy of Management Journal, 53(5), pp.1194-1209.

Lakhani, K., H. Lifshitz-Assaf and M. Tushman (2013). Open innovation and organizational boundaries: the impact of task decomposition and knowledge distribution on the locus of innovation. In: Grandori, A. (Ed.), Handbook of Economic Organization: Integrating Economic and Organization Theory. Edward Elgar, pp. 355-382.

Laursen, K. (2012). 'Keep searching and you'll find: what do we know about variety creation through firms' search activities for innovation?' Industrial and Corporate Change, 21, pp. 1181-1220.

Laursen, K. and Salter, A.J. (2005). 'My Precious: The Role of Appropriability Strategies in Shaping Innovative Performance', DRUID Working Paper 2005-2, Copenhagen.

Laursen, K. and A.J Salter (2006). Open for innovation: the role of openness in explaining innovative performance among UK manufacturing firms. Strategic Management Journal, 27, pp. 131-150.

Laursen, K. and A.J Salter (2014). 'The paradox of openness: Appropriability, external search 
and collaboration', Research Policy, 43(5), pp.867-878.

Lee, L. and P. Wong (2009). 'Firms' Innovative Performance: The Mediating Role of Innovative Collaborations,' MPRA Paper No. 16193.

Leiponen A. (2005) 'Organization of knowledge and innovation: the case of Finnish business services,' Industry and Innovation, 12, pp. 185-203.

Leiponen A and C.E. Helfat (2010) 'Innovation objectives, knowledge sources, and the benefits of breadth, 'Strategic Management Journal, 31, pp. 224-236.

Love, J.H., S. Roper and P. Vahter (2014) 'Learning from openness: The dynamics of breadth in external innovation linkages,' Strategic management journal, 35(11), pp.1703-1716.

$\mathrm{Lu}, \mathrm{J}$. W. and P.W. Beamish (2004). 'International diversification and firm performance: The s-curve hypothesis', The Academy of Management Journal, 47(4), pp. 598-609.

Marshall, A. (1920). Principles of Economics. Macmillan: London.

Maskell, P. (2001). 'Towards a knowledge-based theory of the geographical cluster,' Industrial and Corporate Change, 10(4), 921-944.

Megantz, R.C. (1996). 'How to Licence Technology' John Wiley \& Sons, New York, NY.

Narula, R. and G. Duysters (2004). 'Globalisation and trends in international R\&D alliances', Journal of International Management, 10(2), pp. 199-218.

Nelson, R.R. and S. Winter (1982). An Evolutionary Theory of Economic Change. Harvard University Press: Cambridge, MA.

ONS (2017). Office of National Statistics. UK Innovation Survey. Available at: https://www.ons.gov.uk/surveys/informationforbusinesses/businesssurveys/ukinnovationsurv ey

Ouchi, W.G. and M.K. Bolton (1988) 'The logic of joint research and development'.

California Management Review, 30(3), pp. 9-34.

Pakes, A. and Z. Griliches (1984) Patents and $R$ and D at the Firm Level: a First Look. In: Griliches, Zvi (Ed.), $R \& D$ Patents \& Productivity. University of Chicago Press: Chicago, pp. 55-72.

Penrose, E. T. (1959) The Theory of the Growth of the Firm. New York: John Wiley.

Powell W.W., KW. Koput and L. Smith-Doerr (1996) 'Interorganizational collaboration and the locus of innovation: networks of learning in biotechnology'. Administrative Science Quarterly, 41, pp. 116-145.

Rodríguez, A., M. J. Nieto and L. Santamaría (2018). 'International collaboration and innovation in professional and technological knowledge-intensive services', Industry and Innovation, 25(4), pp. 408-431.

Rogers, M. (2004). 'Networks, Firm Size, and Innovation,' Small Business Economics, 22(2), pp. 141-153.

Roper S, J. Du and J.H. and Love (2008) 'Modelling the innovation value chain'. Research Policy, 37, pp. 961-977.

Roper, S., J. Love and K. Bonner (2017). 'Firms' knowledge search and local knowledge externalities in innovation performance', Research Policy, 46, pp. 43-56.

Rosenkopf, L. and Nerkar, A. (2001). 'Beyond local research: boundary-spanning, exploration, and impact in the optical disk industry', Strategic Management Journal, 22, pp. 287306.

Santamaría, L., M. Nieto and A. Barge-Gil (2009). 'Beyond formal R\&D: Taking advantage of other sources of innovation in low-and medium-technology industries', Research Policy, 38(3), pp. 507-517.

Shan, W., G. Walker and B. Kogut (1994). 'Interfirm cooperation and startup innovation in the biotechnology industry'. Strategic Management Journal, 15, pp. 387-394.

Stuart, T. and J Podolny (1996). 'Local search and the evolution of technological capabilities', Strategic Management Journal, 17, pp. 21-38. 
Teece, D. J. (1986). 'Profiting from technological innovation: Implications for integration, collaboration, licensing and public policy', Research policy, 15(6), pp. 285-305.

Teece, D.J. (1998), "Capturing value from knowledge assets: the new economy, markets for know-how, and intangible assets", California Management Review, Vol. 40 No. 3, pp. 55-79. Teece, D.J. (2000). Managing Intellectual Capital: Organizational, Strategic, and Policy Dimensions, Oxford University Press, Oxford.

Veugelers, R. (1997). Internal R\&D Expenditures and External Technology Sourcing. Research Policy, 26(3), pp. 303-315.

Veugelers, R. (1998). 'Collaboration in R\&D: An Assessment of Theoretical and Empirical Findings'. Economist, 149(3), pp. 419-443.

Veugelers, R. and C. Schneider (2018) 'Which IP strategies do young highly innovative firms choose?' Small Business Economics, 50(1), pp. 113-129.

von Hippel, E. (1994). "Sticky information" and the locus of problem solving: implications for innovation', Management science, 40(4), pp. 429-439.

von Hippel, E. (2005). Democratizing Innovation. MIT Press: Cambridge, MA.

West, J. (2003). 'How open is open enough? Melding proprietary and open source platform strategies', Research Policy, 32 (7), pp. 1259-85.

West, J. and M. Bogers (2014) 'Leveraging external sources of innovation: a review of research on open innovation', Journal of Product Innovation Management, 31(4), pp. 814-831.

West, J., A. Salter, W. Vanhaverbeke and H. Chesbrough (2014). 'Open innovation: The next decade', Research Policy, 43(5), pp. 805-811.

West, J., A. and S. Gallagher (2006). 'Challenges of open innovation: the paradox of firm investment in open-source software’, $R \& D$ Management, 36(3), pp. 319-333.

Wooldridge, J. M. (2009). 'Introductory Econometrics: A Modern Approach', 4th ed. Mason, $\mathrm{OH}$ : South-Western.

Zahra, S.A., R.D. Ireland and M.A. Hitt (2000). 'International expansion by new venture firms: International diversity, mode of market entry, technological learning, and performance,' Academy of Management journal, 43(5), pp.925-950. 
Table 1: Descriptive Statistics

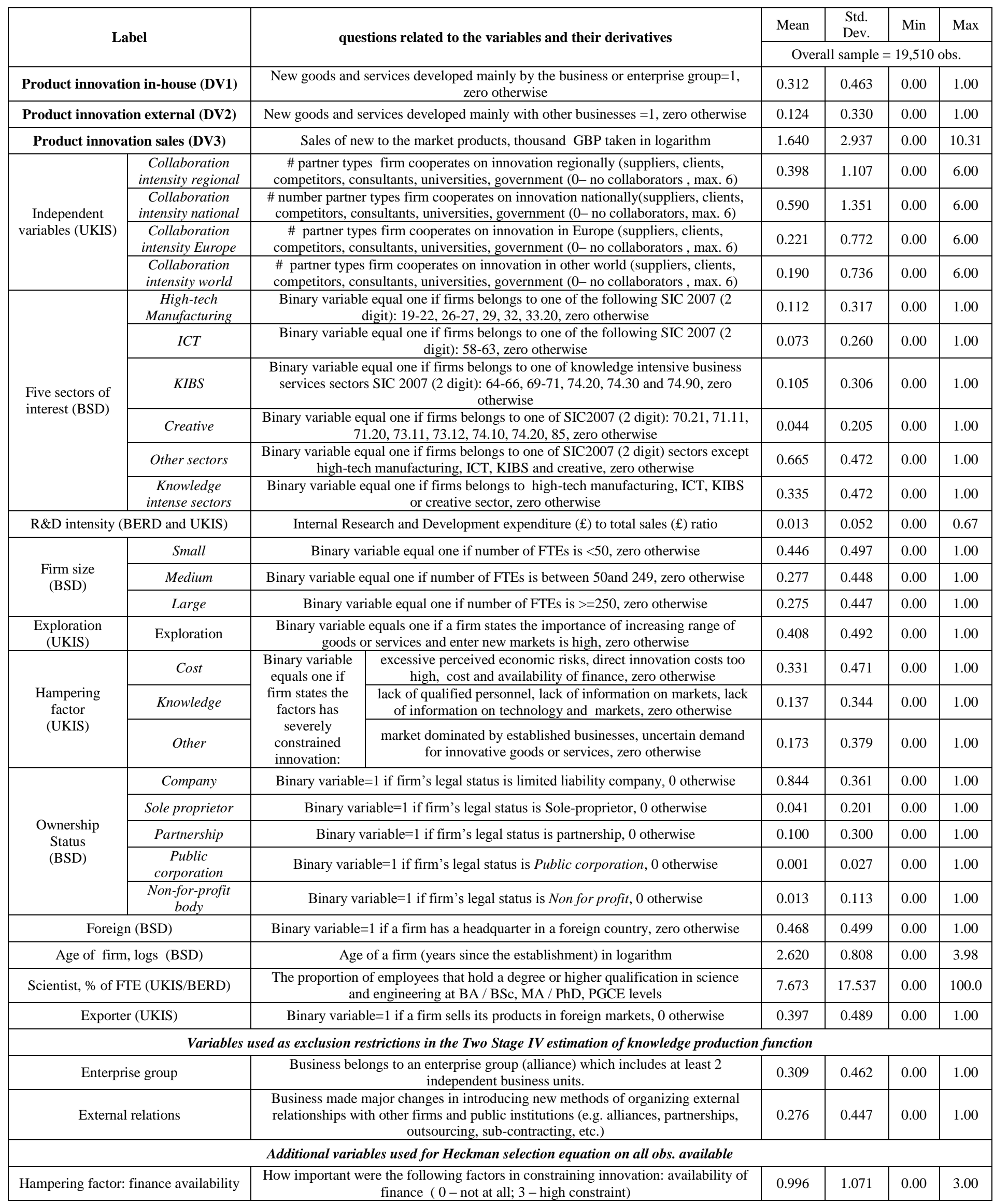




\begin{tabular}{|c|c|c|c|c|c|}
\hline Number of active plant units & Number of active plant units (enterprise units with physical location), in logarithms & 0.984 & 0.938 & 0.00 & 4.941 \\
\hline Market share & $\begin{array}{l}\text { Importance for business to meet regulatory requirements (standards })(0-\text { not } \\
\text { important }-3 \text { very important) }\end{array}$ & 1.409 & 1.219 & 0.00 & 3.00 \\
\hline
\end{tabular}

Source: Department for Business, Innovation and Skills, Office for National Statistics, Northern Ireland. Department of Enterprise, Trade and Investment. (2018). UK Innovation Survey, 1994-2016: Secure Access. [data collection]. 6th Edition. UK Data Service. SN: 6699, http://doi.org/10.5255/UKDA-SN-6699-6 hereinafter named UKIS - UK Innovation Survey (2002-2014).

Office for National Statistics. (2017). Business Structure Database, 1997-2017: Secure Access. [data collection]. 9th Edition. UK Data Service. SN: 6697, http://doi.org/10.5255/UKDA-SN-6697-9 , hereinafter named BSD - Business Register (2002-2014). 
Table 2: Matrix Correlation

\begin{tabular}{|c|c|c|c|c|c|c|c|c|c|c|c|c|c|c|c|c|c|c|}
\hline \multicolumn{2}{|r|}{ Variables } & 1 & 2 & 3 & 4 & 5 & 6 & 7 & 8 & 9 & 10 & 11 & 12 & 13 & 14 & 15 & 16 & 17 \\
\hline 1 & Product innovation in-house & 1 & & & & & & & & & & & & & & & & \\
\hline 2 & Product innovation external & $0.11 *$ & 1 & & & & & & & & & & & & & & & \\
\hline 3 & Product innovation sales & $0.55^{*}$ & $0.24 *$ & 1 & & & & & & & & & & & & & & \\
\hline 4 & Collab intensity regional & $0.13^{*}$ & $0.14 *$ & $0.18^{*}$ & 1 & & & & & & & & & & & & & \\
\hline 5 & Collab intensity national & $0.24 *$ & $0.22 *$ & $0.34 *$ & $0.39 *$ & 1 & & & & & & & & & & & & \\
\hline 6 & Collab intensity Europe & $0.22 *$ & $0.16^{*}$ & $0.31^{*}$ & $0.33^{*}$ & $0.56^{*}$ & 1 & & & & & & & & & & & \\
\hline 7 & Collab intensity world & $0.19^{*}$ & $0.12^{*}$ & $0.28^{*}$ & $0.25^{*}$ & $0.43^{*}$ & $0.59^{*}$ & 1 & & & & & & & & & & \\
\hline 8 & $\mathrm{R} \& \mathrm{D}$ intensity & $0.20^{*}$ & $0.05^{*}$ & $0.19^{*}$ & $0.09^{*}$ & $0.19^{*}$ & $0.21^{*}$ & $0.24 *$ & 1 & & & & & & & & & \\
\hline 9 & Medium & -0.02 & -0.03 & $-0.04 *$ & -0.03 & $-0.03 *$ & $-0.04 *$ & $-0.04 *$ & 0.00 & 1 & & & & & & & & \\
\hline 10 & Large & $0.10^{*}$ & $0.06^{*}$ & $0.16^{*}$ & $0.03^{*}$ & $0.13^{*}$ & $0.14^{*}$ & $0.11^{*}$ & $-0.03 *$ & $-0.37^{*}$ & 1 & & & & & & & \\
\hline 11 & Exploration & $0.24 *$ & $0.16^{*}$ & $0.24 *$ & $0.07^{*}$ & $0.13^{*}$ & $0.11^{*}$ & $0.10^{*}$ & $0.10^{*}$ & -0.00 & $0.04 *$ & 1 & & & & & & \\
\hline 12 & Cost & $0.09^{*}$ & $0.05^{*}$ & $0.11 *$ & $0.11^{*}$ & $0.12 *$ & $0.09 *$ & $0.08^{*}$ & $0.09 *$ & -0.00 & $-0.03 *$ & $0.21 *$ & 1 & & & & & \\
\hline 13 & Knowledge & $0.02^{*}$ & 0.01 & $0.04 *$ & $0.05^{*}$ & $0.05^{*}$ & $0.03 *$ & $0.04 *$ & $0.05^{*}$ & -0.00 & $-0.06^{*}$ & $0.15^{*}$ & $0.35^{*}$ & 1 & & & & \\
\hline 14 & Other & $0.03^{*}$ & $0.01 *$ & $0.03 *$ & $0.05^{*}$ & $0.05^{*}$ & $0.04 *$ & $0.03^{*}$ & $0.04 *$ & -0.00 & $-0.03^{*}$ & $0.15^{*}$ & $0.39^{*}$ & $0.44^{*}$ & 1 & & & \\
\hline 15 & Foreign & $0.11 *$ & $0.06^{*}$ & $0.13 *$ & 0.00 & $0.09 *$ & $0.12 *$ & $0.09 *$ & 0.00 & $0.03 *$ & $0.46^{*}$ & $-0.07 *$ & $-0.08^{*}$ & $-0.09 *$ & $-0.06^{*}$ & 1 & & \\
\hline 16 & Age & 0.01 & $0.02 *$ & $0.02 *$ & 0.00 & $0.01 *$ & $0.02 *$ & 0.00 & $-0.08 *$ & $0.10^{*}$ & $0.19^{*}$ & $-0.02 *$ & $-0.03^{*}$ & $-0.02 *$ & -0.01 & $0.23 *$ & 1 & \\
\hline 17 & Scientist & $0.20^{*}$ & $0.06^{*}$ & $0.22 *$ & $0.08^{*}$ & $0.20^{*}$ & $0.21^{*}$ & $0.23^{*}$ & $0.39^{*}$ & $-0.03^{*}$ & 0.00 & $009^{*}$ & $0.08 *$ & $0.05^{*}$ & $0.04 *$ & $0.04 *$ & $-0.08^{*}$ & 1 \\
\hline 18 & Exporter & $0.32 *$ & $0.15^{*}$ & $0.32 *$ & $0.07 *$ & $0.21^{*}$ & $0.27^{*}$ & $0.24 *$ & $0.17^{*}$ & $0.03^{*}$ & $0.16^{*}$ & $0.14^{*}$ & $0.06^{*}$ & 0.00 & $0.02^{*}$ & $0.20^{*}$ & $0.09 *$ & $0.24 *$ \\
\hline
\end{tabular}

Note: Significance level: $* p<0.05$. Number of obs. $=19,510$

Source: BSD - Business Register (2002-2014) and UKIS - UK Innovation Survey (2002-2014). 
Table 3A: Five aggregated sectors (by SIC 2007)

\begin{tabular}{lrrrrrrr}
\hline \multirow{2}{*}{ Description } & \multicolumn{7}{c}{ Sample of the regressions (DV: Product innovation) } \\
\cline { 2 - 8 } & \multicolumn{1}{c}{2005} & 2007 & 2009 & 2011 & 2013 & 2015 & \multicolumn{1}{c}{ Total } \\
\hline High-tech Manufacturing & 1565 & 312 & 304 & 39 & 19 & 18 & 2257 \\
ICT & 896 & 171 & 195 & 86 & 28 & 43 & 1419 \\
KIBS & 1514 & 149 & 151 & 168 & 28 & 31 & 2041 \\
Creative & 541 & 52 & 89 & 84 & 33 & 54 & 853 \\
Other sectors & 9944 & 781 & 682 & 1181 & 176 & 176 & 12940 \\
Total & & & & & & & 19,510 \\
\hline
\end{tabular}

\begin{tabular}{rrrrrrr}
\hline \multicolumn{7}{c}{ Population sample: (DV: Product innovation) } \\
\hline \multicolumn{1}{c}{2005} & 2007 & 2009 & 2011 & 2013 & \multicolumn{1}{c}{2015} & \multicolumn{1}{c}{ Total } \\
\hline 1692 & 642 & 414 & 77 & 19 & 18 & 2862 \\
994 & 452 & 279 & 347 & 129 & 135 & 2336 \\
1732 & 524 & 231 & 823 & 155 & 175 & 3640 \\
600 & 159 & 119 & 341 & 104 & 140 & 1463 \\
11435 & 2918 & 1208 & 5973 & 1008 & 1136 & 23668 \\
& & & & & & 33,969
\end{tabular}

Note: The totals of rows, which could be used to calculate the number of enterprises in cells $(<10)$ across sectors were suppressed for disclosure control.

Table 3B: Sample distribution by ONS 12 regions

\begin{tabular}{lrrrrrrr}
\hline \multirow{2}{*}{ Description } & \multicolumn{6}{c}{ Sample of the regressions (DV: Product innovation) } \\
\cline { 2 - 7 } & 2005 & 2007 & 2009 & 2011 & 2013 & 2015 & Total \\
\hline North East & 830 & 93 & 85 & 61 & $<20$ & 17 & \\
North West & 1341 & 129 & 117 & 174 & 32 & 23 & \\
Yorkshire and The Humber & 1,179 & 110 & 133 & 126 & $<20$ & 17 & \\
East Midlands & 1178 & 145 & 121 & 121 & $<20$ & 23 & \\
West Midlands & 1,285 & 146 & 122 & 143 & 21 & 19 & \\
Eastern & 1,252 & 143 & 128 & 159 & 25 & 34 & \\
London & 1,401 & 104 & 111 & 170 & 36 & 32 \\
South East & 1543 & 162 & 157 & 203 & 48 & 45 & \\
South West & 1,196 & 127 & 141 & 128 & 27 & 18 & \\
Wales & 975 & 106 & 97 & 74 & $<20$ & 19 & \\
Scotland & 1,115 & 116 & 122 & 104 & $<20$ & 38 & \\
Northern Ireland & 1215 & 84 & 90 & 73 & $<20$ & 22 & \\
\hline Total & & & & & & & 19,510 \\
\end{tabular}

\begin{tabular}{rcrrrrr}
\hline \multicolumn{7}{c}{ Population sample: (DV: Product innovation) } \\
\hline 2005 & 2007 & 2009 & 2011 & 2013 & 2015 & Total \\
\hline 950 & 298 & 135 & 262 & 61 & 76 & \\
1498 & 380 & 198 & 767 & 139 & 130 & \\
1,348 & 363 & 203 & 640 & 116 & 125 & \\
1329 & 397 & 189 & 570 & 112 & 128 & \\
1,456 & 409 & 207 & 650 & 114 & 138 & \\
1,419 & 421 & 176 & 750 & 132 & 152 & \\
1,615 & 495 & 196 & 1006 & 205 & 183 & \\
1738 & 465 & 248 & 1,084 & 228 & 226 & \\
1,361 & 380 & 213 & 637 & 139 & 107 & \\
1,100 & 338 & 155 & 344 & 51 & 97 & \\
1,270 & 360 & 176 & 583 & 78 & 167 & \\
1359 & 389 & 155 & 268 & 40 & 75 & \\
\hline & \multicolumn{7}{c}{} & & 33,969 \\
\end{tabular}

Table 3C: Sample distribution by Size (Micro and Small, Medium and Large)

\begin{tabular}{lccccccc}
\hline \multirow{2}{*}{ Description } & \multicolumn{7}{c}{ Sample of the regressions (DV: Product innovation) } \\
\cline { 2 - 8 } & 2005 & 2007 & 2009 & 2011 & 2013 & 2015 & Total \\
\hline Micro and Small 1-49 & 6,380 & 513 & 558 & 912 & 184 & 178 & \\
Medium 50-249 & 4,098 & 362 & 389 & 404 & 61 & 105 & \\
Large > 249 & 4,032 & 590 & 477 & 220 & 23 & 24 & \\
nyyyyyyyy
\end{tabular}

\begin{tabular}{ccrrrrr}
\hline \multicolumn{7}{c}{ Population sample: (DV: Product innovation) } \\
\hline 2005 & 2007 & 2009 & 2011 & 2013 & 2015 & Total \\
\hline 6,970 & 1934 & 838 & 2166 & 356 & 389 & \\
4,408 & 1034 & 579 & 1016 & 117 & 174 & \\
4,324 & 1452 & 779 & 524 & 58 & 46 & \\
\hline \multicolumn{7}{c}{}
\end{tabular}

Total

19,510

Source: BSD - Business Register (2002-2014) and UKIS - UK Innovation Survey (2002-2014). 
Table 4: Collaboration with external partners by geographic dimensions for four major UK sectors $(\mathrm{N}=19,510)$

Number of firm in the sample

\begin{tabular}{|c|c|c|c|c|c|c|c|c|c|c|c|c|c|c|c|c|}
\hline \multicolumn{17}{|c|}{ Regional } \\
\hline \multirow{2}{*}{\multicolumn{2}{|c|}{ High Tech }} & \multicolumn{2}{|c|}{ Collaboration } & \multirow{2}{*}{ Total } & \multirow{2}{*}{ ICT } & \multicolumn{2}{|c|}{ Collaboration } & \multirow{2}{*}{ Total } & \multirow{2}{*}{ KIBS } & \multicolumn{2}{|c|}{ Collaboration } & & \multirow{2}{*}{ Creative } & \multicolumn{2}{|c|}{ Collaboration } & \\
\hline & & No & Yes & & & No & Yes & & & No & Yes & & & No & Yes & \\
\hline & No & $83.6 \%$ & $16.4 \%$ & 17305 & No & $83.5 \%$ & $16.5 \%$ & 18089 & No & $83.3 \%$ & $16.7 \%$ & 17463 & No & $83.7 \%$ & $16.3 \%$ & 18654 \\
\hline & Yes & $80.3 \%$ & $19.7 \%$ & 2205 & Yes & $80.5 \%$ & $19.5 \%$ & 1421 & Yes & $83.1 \%$ & $16.9 \%$ & 2047 & Yes & $72.7 \%$ & $27.3 \%$ & 856 \\
\hline & Total & 17422 & 2088 & 19510 & Total & 17422 & 2088 & $\begin{array}{l}19510 \\
\text { Nation }\end{array}$ & Total & 17422 & 2088 & 19510 & Total & 17422 & 2088 & 19510 \\
\hline \multirow{2}{*}{\multicolumn{2}{|c|}{ High Tech }} & \multicolumn{2}{|c|}{ Collaboration } & \multirow{2}{*}{ Total } & \multirow{2}{*}{ ICT } & \multicolumn{2}{|c|}{ Collaboration } & \multirow{2}{*}{ Total } & \multirow{2}{*}{ KIBS } & \multicolumn{2}{|c|}{ Collaboration } & & \multirow{2}{*}{ Creative } & \multicolumn{2}{|c|}{ Collaboration } & \\
\hline & & No & Yes & & & No & Yes & & & No & Yes & & & No & Yes & \\
\hline & No & $79.2 \%$ & $20.8 \%$ & 17305 & No & $79.2 \%$ & $20.8 \%$ & 18089 & No & $78.4 \%$ & $21.6 \%$ & 17463 & No & $79.1 \%$ & $20.9 \%$ & 18654 \\
\hline & Yes & $70.7 \%$ & $29.3 \%$ & 2205 & Yes & $66.5 \%$ & $33.5 \%$ & 1421 & Yes & $76.6 \%$ & $23.4 \%$ & 2047 & Yes & $59.3 \%$ & $40.7 \%$ & 856 \\
\hline & Total & 17422 & 2088 & 19510 & Total & 17422 & 2088 & $\begin{array}{l}19510 \\
\text { Europe }\end{array}$ & Total & 17422 & 2088 & 19510 & Total & 17422 & 2088 & 19510 \\
\hline \multirow{2}{*}{\multicolumn{2}{|c|}{ High Tech }} & \multicolumn{2}{|c|}{ Collaboration } & \multirow{2}{*}{ Total } & \multirow{2}{*}{ ICT } & \multicolumn{2}{|c|}{ Collaboration } & \multirow{2}{*}{ Total } & \multirow{2}{*}{ KIBS } & \multicolumn{2}{|c|}{ Collaboration } & & \multirow{2}{*}{ Creative } & Collab & ration & \\
\hline & & No & Yes & & & No & Yes & & & No & Yes & & & No & Yes & \\
\hline & No & $90.3 \%$ & $9.7 \%$ & 17305 & No & $89.7 \%$ & $10.3 \%$ & 18089 & No & $89.0 \%$ & $11.0 \%$ & 17463 & No & $90.0 \%$ & $10.0 \%$ & 18654 \\
\hline & Yes & $81.1 \%$ & $18.9 \%$ & 2205 & Yes & $84.8 \%$ & $15.2 \%$ & 1421 & Yes & $92.0 \%$ & $8.0 \%$ & 2047 & Yes & $73.9 \%$ & $26.1 \%$ & 856 \\
\hline & Total & 17422 & 2088 & 19510 & Total & 17422 & 2088 & $\begin{array}{l}19510 \\
\text { Europe }\end{array}$ & Total & 17422 & 2088 & 19510 & Total & 17422 & 2088 & 19510 \\
\hline High Tech & & Collabo & ration & Total & ICT & Collabo & ation & Total & KIRS & Collabo & ration & & Crogtive & Collab & ration & \\
\hline High Tech & & No & Yes & Iotal & ICT & No & Yes & Iotal & KMBS & No & Yes & & Creative & No & Yes & \\
\hline & No & $91.9 \%$ & $8.1 \%$ & 17305 & No & $91.4 \%$ & $8.6 \%$ & 18089 & No & $90.7 \%$ & $9.3 \%$ & 17463 & No & $91.4 \%$ & $8.6 \%$ & 18654 \\
\hline & Yes & $82.1 \%$ & $17.9 \%$ & 2205 & Yes & $82.4 \%$ & $17.6 \%$ & 1421 & Yes & $91.8 \%$ & $8.2 \%$ & 2047 & Yes & $76.7 \%$ & $23.3 \%$ & 856 \\
\hline & Total & 17711 & 1799 & 19510 & Total & 17711 & 1799 & 19510 & Total & 17711 & 1799 & 19510 & Total & 17711 & 1799 & 19510 \\
\hline
\end{tabular}

Source: BSD - Business Register (2002-2014) and UKIS - UK Innovation Survey (2002-2014). 
Table 5. Knowledge production function (second-stage) across five UK industries

\begin{tabular}{|c|c|c|c|c|c|c|}
\hline Specification & (1) & (2) & (3) & (4) & (5) & (6) \\
\hline Dependent variable & \multicolumn{6}{|c|}{$\begin{array}{c}\text { Product innovation in-house (new to market products/ services were developed mainly by } \\
\text { business) }\end{array}$} \\
\hline Sectors & $\begin{array}{c}\text { High-tech } \\
\text { manufacturing }\end{array}$ & ICT & KIBS & Creative & Other sectors & All sample \\
\hline Method & IV probit & IV probit & IV probit & IV probit & IV probit & IV probit \\
\hline Collab. intensity (region) $\widehat{\varphi}_{l}$ & $\begin{array}{c}0.03 \\
(0.02) \\
\end{array}$ & $\begin{array}{c}0.13 * * \\
(0.04)\end{array}$ & $\begin{array}{l}0.08^{*} \\
(0.03) \\
\end{array}$ & $\begin{array}{c}0.01 \\
(0.04) \\
\end{array}$ & $\begin{array}{c}0.09^{* * *} \\
(0.01)\end{array}$ & $\begin{array}{c}0.09^{* * *} \\
(0.11)\end{array}$ \\
\hline Collab. intensity (national) $\widehat{\varphi}_{l}$ & $\begin{array}{c}0.03 \\
(0.02)\end{array}$ & $\begin{array}{l}0.07 * \\
(0.03)\end{array}$ & $\begin{array}{c}0.08 * * \\
(0.03)\end{array}$ & $\begin{array}{l}0.06^{*} \\
(0.03)\end{array}$ & $\begin{array}{c}0.09 * * * \\
(0.01)\end{array}$ & $\begin{array}{c}0.08 * * * \\
(0.01)\end{array}$ \\
\hline Collab. intensity (Europe) $\widehat{\varphi}_{l}$ & $\begin{array}{c}0.01 \\
(0.01)\end{array}$ & $\begin{array}{c}0.08 \\
(0.09)\end{array}$ & $\begin{array}{c}0.08 \\
(0.66)\end{array}$ & $\begin{array}{c}0.04 \\
(0.03)\end{array}$ & $\begin{array}{c}0.04 \\
(0.03)\end{array}$ & $\begin{array}{c}0.01 \\
(0.01)\end{array}$ \\
\hline Collab. intensity (world) $\widehat{\varphi}_{l}$ & $\begin{array}{c}0.02 \\
(0.03)\end{array}$ & $\begin{array}{c}0.01 \\
(0.01)\end{array}$ & $\begin{array}{c}0.02 \\
(0.02)\end{array}$ & $\begin{array}{c}0.01 \\
(0.00)\end{array}$ & $\begin{array}{c}0.01 \\
(0.02)\end{array}$ & $\begin{array}{c}0.01 \\
(0.03)\end{array}$ \\
\hline Standardized R\&D intensity & $\begin{array}{c}0.20 * * * \\
(0.04)\end{array}$ & $\begin{array}{c}0.23 * * * \\
(0.03)\end{array}$ & $\begin{array}{c}031 * * * \\
(0.05)\end{array}$ & $\begin{array}{c}0.06^{* *} \\
(0.02)\end{array}$ & $\begin{array}{c}0.31 \text { *** } \\
(0.03)\end{array}$ & $\begin{array}{c}0.15^{* * *} * \\
(0.01)\end{array}$ \\
\hline Medium & $\begin{array}{c}0.12 \\
(0.17) \\
\end{array}$ & $\begin{array}{c}0.16 \\
(0.17) \\
\end{array}$ & $\begin{array}{c}0.14 \\
(0.09) \\
\end{array}$ & $\begin{array}{c}-0.11 \\
(0.12) \\
\end{array}$ & $\begin{array}{c}0.02 \\
(0.03) \\
\end{array}$ & $\begin{array}{c}0.03 \\
(0.03) \\
\end{array}$ \\
\hline Large & $\begin{array}{c}0.16 \\
(0.52) \\
\end{array}$ & $\begin{array}{l}-0.12 \\
(0.42) \\
\end{array}$ & $\begin{array}{l}0.26 * * \\
(0.09)\end{array}$ & $\begin{array}{c}0.14 \\
(0.15) \\
\end{array}$ & $\begin{array}{l}0.07 * * \\
(0.03) \\
\end{array}$ & $\begin{array}{c}0.05 \\
(0.02) \\
\end{array}$ \\
\hline Exploration & $\begin{array}{c}0.44 * * * \\
(0.06)\end{array}$ & $\begin{array}{c}0.25^{* * * *} \\
(0.08)\end{array}$ & $\begin{array}{l}0.39^{*} \\
(0.17) \\
\end{array}$ & $\begin{array}{c}0.53 * * * \\
(0.10) \\
\end{array}$ & $\begin{array}{c}0.33 * * * \\
(0.02) \\
\end{array}$ & $\begin{array}{c}0.36^{* * *} \\
(0.02) \\
\end{array}$ \\
\hline Hampering factor: cost of innovation & $\begin{array}{l}-0.09 \\
(0.06) \\
\end{array}$ & $\begin{array}{c}0.03 \\
(0.11) \\
\end{array}$ & $\begin{array}{c}0.08 \\
(0.11) \\
\end{array}$ & $\begin{array}{c}0.07 \\
(0.16) \\
\end{array}$ & $\begin{array}{c}0.05 \\
(0.03) \\
\end{array}$ & $\begin{array}{l}0.04^{*} \\
(0.02) \\
\end{array}$ \\
\hline Hampering factor: knowledge on market & $\begin{array}{c}-0.21 * * \\
(0.08)\end{array}$ & $\begin{array}{c}-0.55 * * * \\
(0.09)\end{array}$ & $\begin{array}{c}-0.48^{* *} \\
(0.09)\end{array}$ & $\begin{array}{l}-0.20^{*} \\
(0.10)\end{array}$ & $\begin{array}{c}-0.35 * * * \\
(0.04)\end{array}$ & $\begin{array}{c}-0.35 * * * \\
(0.03)\end{array}$ \\
\hline Hampering factor: other & $\begin{array}{c}-0.22 * * \\
(0.07) \\
\end{array}$ & $\begin{array}{l}-0.23 * \\
(0.10)\end{array}$ & $\begin{array}{c}-0.25^{* *} \\
(0.10) \\
\end{array}$ & $\begin{array}{l}-0.24 \\
(0.17)\end{array}$ & $\begin{array}{c}-0.23 * * * \\
(0.04) \\
\end{array}$ & $\begin{array}{c}-0.25 * * * \\
(0.02) \\
\end{array}$ \\
\hline Foreign & $\begin{array}{c}0.21 \\
(0.53)\end{array}$ & $\begin{array}{c}0.05 \\
(0.08)\end{array}$ & $\begin{array}{l}-0.29 \\
(0.39) \\
\end{array}$ & $\begin{array}{l}-0.05 \\
(0.11)\end{array}$ & $\begin{array}{c}0.49 \\
(0.25)\end{array}$ & $\begin{array}{c}0.36 \\
(0.22)\end{array}$ \\
\hline Age of firm & $\begin{array}{l}-0.02 \\
(0.06)\end{array}$ & $\begin{array}{l}-0.02 \\
(0.05)\end{array}$ & $\begin{array}{l}-0.08^{*} \\
(0.04)\end{array}$ & $\begin{array}{l}-0.16 \\
(0.10)\end{array}$ & $\begin{array}{c}-0.06 * * * \\
(0.01)\end{array}$ & $\begin{array}{c}-0.05^{* * * *} \\
(0.01)\end{array}$ \\
\hline Standardized Scientist & $\begin{array}{c}0.15^{* * * *} \\
(0.04)\end{array}$ & $\begin{array}{c}0.14 \text { *** } \\
(0.02)\end{array}$ & $\begin{array}{c}0.10^{* * * *} \\
(0.02)\end{array}$ & $\begin{array}{c}0.07 * * * \\
(0.02)\end{array}$ & $\begin{array}{c}0.13^{* * * *} \\
(0.01)\end{array}$ & $\begin{array}{c}0.12 * * * \\
(0.01)\end{array}$ \\
\hline Exporter & $\begin{array}{c}0.88^{* * * *} \\
(0.07) \\
\end{array}$ & $\begin{array}{c}0.39 * * * \\
(0.07) \\
\end{array}$ & $\begin{array}{c}0.45^{* * * *} \\
(0.07) \\
\end{array}$ & $\begin{array}{c}0.42^{* * * *} \\
(0.11) \\
\end{array}$ & $\begin{array}{l}0.50^{* * *} \\
(0.03)\end{array}$ & $\begin{array}{c}0.55^{* * * *} \\
(0.02)\end{array}$ \\
\hline Legal status dummies & Yes & Yes & Yes & Yes & Yes & Yes \\
\hline Industry, survey wave and the UK region dummies & Yes & Yes & Yes & Yes & Yes & Yes \\
\hline Constant & $\begin{array}{c}-1.08 * * * * \\
(0.16) \\
\end{array}$ & $\begin{array}{c}-0.89 * * * \\
(0.22) \\
\end{array}$ & $\begin{array}{c}-1.32 * * * \\
(0.22) \\
\end{array}$ & $\begin{array}{c}-0.63 * * \\
(0.24) \\
\end{array}$ & $\begin{array}{c}-1.05 * * * \\
(0.13) \\
\end{array}$ & $\begin{array}{c}-1.08 * * * \\
(0.13) \\
\end{array}$ \\
\hline Number of observations & 2257 & 1419 & 2041 & 853 & 12940 & 19510 \\
\hline Chi2 & 704.90 & 351.93 & 519.41 & 238.24 & 3332.05 & 5590.10 \\
\hline Log-likelihood & -1355.90 & -892.92 & -1034.76 & -483.36 & -6959.60 & -10952.20 \\
\hline
\end{tabular}

Note: standard errors robust for hereroskedastisity are in parenthesis. Reference groups: small firm (10-49 FTEs); legal ownership (listed company); UK region (North East); survey wave (2002-2004). Industry (1 digit SIC), UK region and year fixed effects were suppressed to save space. Significance level: * $p<0.05 ; * * p<0.01$; $^{* * *} \mathrm{p}<0.001 "$.

Source: BSD - Business Register (2002-2014) and UKIS - UK Innovation Survey (2002-2014). 
Table 6. Knowledge production function (second-stage): knowledge intense sectors vs. other sectors

\begin{tabular}{|c|c|c|c|c|c|c|c|c|c|c|c|c|}
\hline & (1) & (2) & (3) & (4) & (5) & (6) & (7) & (8) & (9) & (10) & (11) & (12) \\
\hline Method & Probit & Probit & Probit & Probit & Probit & Probit & Probit & Probit & Tobit & Tobit & Tobit & Tobit \\
\hline Dependent variable & \multicolumn{4}{|c|}{$\begin{array}{c}\text { New goods and services developed by business } \\
\text { or / and enterprise group=1 }\end{array}$} & \multicolumn{4}{|c|}{$\begin{array}{c}\text { New goods and services developed by business } \\
\text { with other businesses }=1\end{array}$} & \multicolumn{4}{|c|}{ New product sales, (logs) } \\
\hline Collaboration region & regional & national & Europe & world & regional & national & Europe & world & regional & national & Europe & world \\
\hline Knowledge intense sectors (KIS) & $\begin{array}{l}0.06^{*} \\
(0.03)\end{array}$ & $\begin{array}{l}0.07^{*} \\
(0.02)\end{array}$ & $\begin{array}{l}0.07 * \\
(0.03)\end{array}$ & $\begin{array}{l}0.06^{*} \\
(0.03)\end{array}$ & $\begin{array}{l}-0.09 \\
(0.08)\end{array}$ & $\begin{array}{l}-0.07 \\
(0.06)\end{array}$ & $\begin{array}{l}-0.11 \\
(0.07)\end{array}$ & $\begin{array}{ll}-0.16^{*} \\
(0.07)\end{array}$ & $\begin{array}{c}0.85 * * * \\
(0.25)\end{array}$ & $\begin{array}{c}0.79 * * * \\
(0.23)\end{array}$ & $\begin{array}{c}0.87 * * * \\
(0.23)\end{array}$ & $\begin{array}{c}0.80^{* * * *} \\
(0.23)\end{array}$ \\
\hline Collab. intensity (region) $\widehat{\varphi}_{l}(\boldsymbol{H I})$ & $\begin{array}{c}0.10^{* * * *} \\
(0.01)\end{array}$ & $\begin{array}{c}0.08 * * * \\
(0.01)\end{array}$ & $\begin{array}{c}0.08^{* * * *} \\
(0.01)\end{array}$ & $\begin{array}{c}0.09^{* * *} \\
(0.01)\end{array}$ & $\begin{array}{c}0.11 * * * \\
(0.01)\end{array}$ & $\begin{array}{c}0.12 * * * \\
(0.01)\end{array}$ & $\begin{array}{c}0.12 * * * \\
(0.01)\end{array}$ & $\begin{array}{c}0.12^{* * * *} \\
(0.01)\end{array}$ & $\begin{array}{c}0.69 * * * \\
(0.07)\end{array}$ & $\begin{array}{c}0.62^{* * *} \\
(0.06)\end{array}$ & $\begin{array}{c}0.64 * * * \\
(0.07)\end{array}$ & $\begin{array}{c}0.65^{* * * *} \\
(0.06)\end{array}$ \\
\hline Collab. intensity (national) $\widehat{\varphi}_{l}(\boldsymbol{H I})$ & $\begin{array}{c}0.07 * * * \\
(0.00)\end{array}$ & $\begin{array}{c}0.10^{* * * *} \\
(0.01)\end{array}$ & $\begin{array}{c}0.07^{* * * *} \\
(0.00)\end{array}$ & $\begin{array}{c}0.07 * * * \\
(0.00)\end{array}$ & $\begin{array}{c}0.14 * * * \\
(0.01) \\
\end{array}$ & $\begin{array}{c}0.17 * * * \\
(0.00) \\
\end{array}$ & $\begin{array}{c}0.14 * * * * \\
(0.00)\end{array}$ & $\begin{array}{c}0.14^{* * * *} \\
(0.01)\end{array}$ & $\begin{array}{c}0.92^{* * * *} \\
(0.05)\end{array}$ & $\begin{array}{c}1.04 * * * \\
(0.06)\end{array}$ & $\begin{array}{c}0.91 * * * \\
(0.05)\end{array}$ & $\begin{array}{c}0.91 * * * * \\
(0.05)\end{array}$ \\
\hline Collab. intensity (Europe) $\widehat{\varphi}_{l}(\boldsymbol{H I})$ & $\begin{array}{l}0.02 * * \\
(0.01)\end{array}$ & $\begin{array}{l}0.02 * \\
(0.01)\end{array}$ & $\begin{array}{c}0.06^{* *} \\
(0.02)\end{array}$ & $\begin{array}{l}0.01 * \\
(0.00)\end{array}$ & $\begin{array}{c}0.02 \\
(0.02)\end{array}$ & $\begin{array}{c}0.02 \\
(0.02)\end{array}$ & $\begin{array}{c}0.02 \\
(0.10)\end{array}$ & $\begin{array}{c}0.01 \\
(0.02)\end{array}$ & $\begin{array}{c}0.03 \\
(0.10)\end{array}$ & $\begin{array}{c}0.04 \\
(0.07)\end{array}$ & $\begin{array}{c}0.30^{* * *} \\
(0.09)\end{array}$ & $\begin{array}{l}0.05^{*} \\
(0.02)\end{array}$ \\
\hline Collab. intensity (world) $\widehat{\varphi}_{l}(\boldsymbol{H I})$ & $\begin{array}{c}0.97 \\
(0.99)\end{array}$ & $\begin{array}{c}0.99 \\
(0.98)\end{array}$ & $\begin{array}{c}0.95 \\
(0.99)\end{array}$ & $\begin{array}{c}0.96 \\
(0.80)\end{array}$ & $\begin{array}{c}0.75 \\
(1.11)\end{array}$ & $\begin{array}{c}0.95 \\
(1.21)\end{array}$ & $\begin{array}{c}0.74 \\
(1.12)\end{array}$ & $\begin{array}{c}0.72 \\
(1.16)\end{array}$ & $\begin{array}{c}9.93 \\
(4.61)\end{array}$ & $\begin{array}{c}9.95 \\
(4.76)\end{array}$ & $\begin{array}{c}9.81 \\
(4.61)\end{array}$ & $\begin{array}{c}9.98 \\
(4.84)\end{array}$ \\
\hline KIS $\mathrm{x}$ collab. intensity by region & $\begin{array}{l}0.04 * \\
(0.01)\end{array}$ & $\begin{array}{l}0.02 * \\
(0.01)\end{array}$ & $\begin{array}{l}0.02 * \\
(0.01)\end{array}$ & $\begin{array}{l}0.02 * \\
(0.01)\end{array}$ & $\begin{array}{c}-0.02 * \\
(0.01)\end{array}$ & $\begin{array}{c}-0.02 * \\
(0.01) \\
\end{array}$ & $\begin{array}{c}-0.02 * \\
(0.01)\end{array}$ & $\begin{array}{c}-0.03 * \\
(0.01)\end{array}$ & $\begin{array}{c}0.78 * * * * \\
(0.23)\end{array}$ & $\begin{array}{c}0.76^{* * * *} \\
(0.22)\end{array}$ & $\begin{array}{c}0.77 * * * \\
(0.23)\end{array}$ & $\begin{array}{c}0.71 * * * * \\
(0.35)\end{array}$ \\
\hline Standardized R\&D intensity & $\begin{array}{c}0.33^{* * *} * \\
(0.03)\end{array}$ & $\begin{array}{c}0.35^{* * *} \\
(0.03)\end{array}$ & $\begin{array}{c}0.34 * * * * \\
(0.04)\end{array}$ & $\begin{array}{c}0.34 * * * \\
(0.04)\end{array}$ & $\begin{array}{l}0.07^{*} \\
(0.03)\end{array}$ & $\begin{array}{c}.11 \text { *** } \\
(0.04) \\
\end{array}$ & $\begin{array}{l}0.08^{*} \\
(0.04)\end{array}$ & $\begin{array}{l}0.07^{*} \\
(0.03)\end{array}$ & $\begin{array}{c}1.58 * * * * \\
(0.18)\end{array}$ & $\begin{array}{r}1.85 * * * * \\
(0.19)\end{array}$ & $\begin{array}{r}1.67^{* * * * *} \\
(0.19) \\
\end{array}$ & $\begin{array}{c}1.52 * * * * \\
(0.20)\end{array}$ \\
\hline KIS x Standardized R\&D intensity & $\begin{array}{c}-0.18^{* * * *} \\
(0.03)\end{array}$ & $\begin{array}{c}-0.17 \text { **** } \\
(0.03)\end{array}$ & $\begin{array}{c}-0.17 * * * \\
(0.03)\end{array}$ & $\begin{array}{c}-0.16^{* * * * *} \\
(0.04)\end{array}$ & $\begin{array}{c}-0.10^{* * * *} \\
(0.03)\end{array}$ & $\begin{array}{c}-0.16^{* * * *} \\
(0.04)\end{array}$ & $\begin{array}{c}-0.11 * * * * \\
(0.03)\end{array}$ & $\begin{array}{c}-0.11 * * * \\
(0.03)\end{array}$ & $\begin{array}{c}-1.13^{* * * *} \\
(0.23)\end{array}$ & $\begin{array}{c}-1.30^{* * * *} \\
(0.22)\end{array}$ & $\begin{array}{c}-1.21 * * * * \\
(0.21)\end{array}$ & $\begin{array}{c}-1.04 * * * * \\
(0.22)\end{array}$ \\
\hline $\begin{array}{c}\text { Collab. intensity } x \text { Standardized } R \& D \text { intensity }(\mathrm{H} 2 \& \\
H 4)\end{array}$ & $\begin{array}{l}-0.03^{*} \\
(0.02)\end{array}$ & $\begin{array}{c}-0.05^{* *} \\
(0.02)\end{array}$ & $\begin{array}{c}-0.04 * * \\
(0.02)\end{array}$ & $\begin{array}{l}-0.06^{*} \\
(0.03)\end{array}$ & $\begin{array}{l}-0.02 * \\
(0.01)\end{array}$ & $\begin{array}{c}-0.04 * * \\
(0.01)\end{array}$ & $\begin{array}{l}-0.02 \% \\
(0.01)\end{array}$ & $\begin{array}{l}-0.02 \\
(0.02)\end{array}$ & $\begin{array}{c}-0.45^{* * * * *} \\
(0.10)\end{array}$ & $\begin{array}{c}-0.59 * * * \\
(0.08)\end{array}$ & $\begin{array}{c}-0.60^{* * * * *} \\
(0.11)\end{array}$ & $\begin{array}{c}-0.53 * * * \\
(0.12)\end{array}$ \\
\hline$\underset{(\mathrm{H} 3)}{\mathrm{KIS} x \text { Collab. intensity } x \text { Standardized } R \& D \text { intensity }}$ & $\begin{array}{c}0.02 \\
(0.01)\end{array}$ & $\begin{array}{c}0.01 \\
(0.01)\end{array}$ & $\begin{array}{c}0.01 \\
(0.01)\end{array}$ & $\begin{array}{c}0.01 \\
(0.01)\end{array}$ & $\begin{array}{l}0.03 * * \\
(0.01)\end{array}$ & $\begin{array}{c}0.05 * * * * \\
(0.01)\end{array}$ & $\begin{array}{l}0.03 * \\
(0.01)\end{array}$ & $\begin{array}{c}0.03 \\
(0.02)\end{array}$ & $\begin{array}{l}0.27 * * \\
(0.12)\end{array}$ & $\begin{array}{l}0.46^{* * * *} \\
(0.09)\end{array}$ & $\begin{array}{l}0.47 * * * \\
(0.12)\end{array}$ & $\begin{array}{l}0.38 * * \\
(0.12)\end{array}$ \\
\hline Standardized Scientist & $\begin{array}{c}0.16^{* * * *} \\
(0.02)\end{array}$ & $\begin{array}{c}0.16 * * * \\
(0.02)\end{array}$ & $\begin{array}{c}0.15^{* * * *} \\
(0.03)\end{array}$ & $\begin{array}{c}0.15 * * * \\
(0.02)\end{array}$ & $\begin{array}{c}0.07 * * \\
(0.02)\end{array}$ & $\begin{array}{c}0.07 * * * \\
(0.02)\end{array}$ & $\begin{array}{c}0.08 * * * \\
(0.02)\end{array}$ & $\begin{array}{c}0.08 * * * \\
(0.02)\end{array}$ & $\begin{array}{c}1.25 * * * \\
(0.13)\end{array}$ & $\begin{array}{c}1.23^{* * * *} \\
(0.13)\end{array}$ & $\begin{array}{c}1.20 * * * \\
(0.13)\end{array}$ & $\begin{array}{c}1.25 * * * \\
(0.13)\end{array}$ \\
\hline KIS x Standardized Scientist & $\begin{array}{l}-0.03 \\
(0.06)\end{array}$ & $\begin{array}{c}-0.01 \\
(0.03)\end{array}$ & $\begin{array}{l}-0.04 \\
(0.04)\end{array}$ & $\begin{array}{l}-0.03 \\
(0.03)\end{array}$ & $\begin{array}{c}-0.08^{* *} \\
(0.03)\end{array}$ & $\begin{array}{c}-0.06 * * \\
(0.02)\end{array}$ & $\begin{array}{c}-0.09^{* *} \\
(0.03)\end{array}$ & $\begin{array}{c}-0.08 * * \\
(0.02)\end{array}$ & $\begin{array}{c}-0.47 * * * \\
(0.15)\end{array}$ & $\begin{array}{c}-0.39 * * * \\
(0.16)\end{array}$ & $\begin{array}{c}-0.39 * * * * \\
(0.15)\end{array}$ & $\begin{array}{c}-0.46 * * * * \\
(0.15)\end{array}$ \\
\hline Collab. intensity $x$ Standardized Scientist $(\mathrm{H} 2 \& H 4)$ & $\begin{array}{c}0.05^{* * *} \\
(0.01)\end{array}$ & $\begin{array}{l}-0.01 * \\
(0.00)\end{array}$ & $\begin{array}{c}-0.01 \\
(0.01)\end{array}$ & $\begin{array}{c}-0.01 \\
(0.02)\end{array}$ & $\begin{array}{c}-0.06 * * * * \\
(0.01)\end{array}$ & $\begin{array}{c}-0.04 * * * * \\
(0.01)\end{array}$ & $\begin{array}{c}-0.05 \% * * \\
(0.02)\end{array}$ & $\begin{array}{c}-0.04 * * * * \\
(0.01)\end{array}$ & $\begin{array}{c}-0.31^{* * * * *} \\
(0.09)\end{array}$ & $\begin{array}{c}-0.17 * * * \\
(0.06)\end{array}$ & $\begin{array}{c}0.21 * * * \\
(0.09)\end{array}$ & $\begin{array}{c}-0.25 * * \\
(0.09)\end{array}$ \\
\hline KIS $x$ Collab. intensity $x$ Standardized Scientist $(H 3)$ & $\begin{array}{c}-0.01 \\
(0.01)\end{array}$ & $\begin{array}{c}-0.01 \\
(0.00)\end{array}$ & $\begin{array}{c}-0.01 \\
(0.01)\end{array}$ & $\begin{array}{c}-0.01 \\
(0.01)\end{array}$ & $\begin{array}{c}0.03 \\
(0.02)\end{array}$ & $\begin{array}{c}0.02 \\
(0.01)\end{array}$ & $\begin{array}{c}0.02 \\
(0.01)\end{array}$ & $\begin{array}{c}0.02 \\
(0.01)\end{array}$ & $\begin{array}{c}0.14 \\
(0.11)\end{array}$ & $\begin{array}{c}0.01 \\
(0.06)\end{array}$ & $\begin{array}{c}0.04 \\
(0.11)\end{array}$ & $\begin{array}{c}-0.08 \\
(0.12) \\
\end{array}$ \\
\hline Medium & $\begin{array}{c}0.21^{* * *} \\
(0.05)\end{array}$ & $\begin{array}{c}0.20^{* * *} \\
(0.05)\end{array}$ & $\begin{array}{c}0.21^{* * * *} \\
(0.05)\end{array}$ & $\begin{array}{c}0.21 * * * \\
(0.05)\end{array}$ & $\begin{array}{c}0.01 \\
(0.06)\end{array}$ & $\begin{array}{c}0.02 \\
(0.06) \\
\end{array}$ & $\begin{array}{c}0.01 \\
(0.06)\end{array}$ & $\begin{array}{c}0.01 \\
(0.06) \\
\end{array}$ & $\begin{array}{c}0.61 \\
(0.33) \\
\end{array}$ & $\begin{array}{c}0.66^{* *} \\
(0.30) \\
\end{array}$ & $\begin{array}{l}0.69 * \\
(0.33) \\
\end{array}$ & $\begin{array}{l}0.66^{*} \\
(0.33) \\
\end{array}$ \\
\hline Large & $\begin{array}{c}0.26^{* * *} \\
(0.09)\end{array}$ & $\begin{array}{c}0.24 * * * \\
(0.05)\end{array}$ & $\begin{array}{c}0.21^{* *} \\
(0.09)\end{array}$ & $\begin{array}{c}0.22 * * \\
(0.08)\end{array}$ & $\begin{array}{c}0.01 \\
(0.15)\end{array}$ & $\begin{array}{c}0.01 \\
(0.09)\end{array}$ & $\begin{array}{c}0.01 \\
(0.15)\end{array}$ & $\begin{array}{c}0.01 \\
(0.15)\end{array}$ & $\begin{array}{c}3.36^{* * * * *} \\
(0.83) \\
\end{array}$ & $\begin{array}{c}3.22 * * * \\
(0.83) \\
\end{array}$ & $\begin{array}{c}3.01 * * * \\
(0.83)\end{array}$ & $\begin{array}{c}3.07 * * * * \\
(0.83)\end{array}$ \\
\hline Exploration & $\begin{array}{c}0.36 * * * \\
(0.02)\end{array}$ & $\begin{array}{c}0.36 * * * \\
(0.02)\end{array}$ & $\begin{array}{c}0.36 * * * * \\
(0.02)\end{array}$ & $\begin{array}{c}0.36 * * * \\
(0.02)\end{array}$ & $\begin{array}{c}0.20 * * * * \\
(0.03)\end{array}$ & $\begin{array}{c}0.19 * * * \\
(0.03)\end{array}$ & $\begin{array}{c}0.20 * * * * \\
(0.03)\end{array}$ & $\begin{array}{c}0.20^{* * * *} \\
(0.03)\end{array}$ & $\begin{array}{c}2.35 \text { **** } \\
(0.15)\end{array}$ & $\begin{array}{c}2.38^{* * * *} \\
(0.15)\end{array}$ & $\begin{array}{c}2.49 * * * \\
(0.15)\end{array}$ & $\begin{array}{c}2.51 * * * * \\
(0.15)\end{array}$ \\
\hline Hampering factor: cost of innovation & $\begin{array}{l}0.04 * \\
(0.02)\end{array}$ & $\begin{array}{l}0.04 * \\
(0.02)\end{array}$ & $\begin{array}{l}0.04 * \\
(0.02)\end{array}$ & $\begin{array}{l}0.04 * \\
(0.02)\end{array}$ & $\begin{array}{c}0.04 \\
(0.04)\end{array}$ & $\begin{array}{c}0.04 \\
(0.04)\end{array}$ & $\begin{array}{c}0.04 \\
(0.04)\end{array}$ & $\begin{array}{c}0.04 \\
(0.04)\end{array}$ & $\begin{array}{c}0.71 * * * * \\
(0.15)\end{array}$ & $\begin{array}{c}0.70^{* * *} \\
(0.15)\end{array}$ & $\begin{array}{c}0.73 * * * \\
(0.15)\end{array}$ & $\begin{array}{c}0.71 * * * * \\
(0.15)\end{array}$ \\
\hline Hampering factor: knowledge on market & $\begin{array}{c}-0.35^{* * * *} \\
(0.03)\end{array}$ & $\begin{array}{c}-0.35 * * * * \\
(0.03)\end{array}$ & $\begin{array}{c}-0.35^{* * * *} \\
(0.03)\end{array}$ & $\begin{array}{c}-0.35 * * * * \\
(0.03)\end{array}$ & $\begin{array}{c}-0.36 * * * * \\
(0.04)\end{array}$ & $\begin{array}{c}-0.36 * * * * \\
(0.04)\end{array}$ & $\begin{array}{c}-0.36 * * * * \\
(0.04)\end{array}$ & $\begin{array}{c}-0.36 * * * \\
(0.04)\end{array}$ & $\begin{array}{c}-1.57^{* * * *} \\
(0.22)\end{array}$ & $\begin{array}{c}-1.57 * * * * \\
(0.22)\end{array}$ & $\begin{array}{c}-1.57 * * * * \\
(0.22)\end{array}$ & $\begin{array}{c}-1.57 * * * * \\
(0.22)\end{array}$ \\
\hline Hampering factor: other & $\begin{array}{c}-0.24 * * * \\
(0.03)\end{array}$ & $\begin{array}{c}-0.24 * * * * \\
(0.03)\end{array}$ & $\begin{array}{c}-0.25 * * * \\
(0.03)\end{array}$ & $\begin{array}{c}-0.24 * * * * \\
(0.03)\end{array}$ & $\begin{array}{c}-0.19 * * * \\
(0.04)\end{array}$ & $\begin{array}{c}-0.19^{* * * *} \\
(0.04)\end{array}$ & $\begin{array}{c}-0.19 * * * \\
(0.05)\end{array}$ & $\begin{array}{c}-0.19 * * * \\
(0.04)\end{array}$ & $\begin{array}{c}-1.16^{* * * *} \\
(0.26)\end{array}$ & $\begin{array}{c}-1.16^{* * * *} \\
(0.26)\end{array}$ & $\begin{array}{c}-1.12 * * * * \\
(0.26)\end{array}$ & $\begin{array}{c}-1.11^{* * * *} \\
(0.26)\end{array}$ \\
\hline
\end{tabular}




\begin{tabular}{|c|c|c|c|c|c|c|c|c|c|c|c|c|}
\hline Foreign & $\begin{array}{c}0.01 \\
(0.02) \\
\end{array}$ & $\begin{array}{c}0.01 \\
(0.02) \\
\end{array}$ & $\begin{array}{c}0.01 \\
(0.02) \\
\end{array}$ & $\begin{array}{c}0.01 \\
(0.02) \\
\end{array}$ & $\begin{array}{c}0.03 \\
(0.03) \\
\end{array}$ & $\begin{array}{c}0.03 \\
(0.03) \\
\end{array}$ & $\begin{array}{c}0.03 \\
(0.03) \\
\end{array}$ & $\begin{array}{c}0.03 \\
(0.03) \\
\end{array}$ & $\begin{array}{c}0.08 \\
(0.16) \\
\end{array}$ & $\begin{array}{c}0.08 \\
(0.16) \\
\end{array}$ & $\begin{array}{c}0.08 \\
(0.16) \\
\end{array}$ & $\begin{array}{c}0.04 \\
(0.16) \\
\end{array}$ \\
\hline Age of firm & $\begin{array}{l}-0.08^{*} \\
(0.01) \\
\end{array}$ & $\begin{array}{c}-0.08^{*} \\
(0.01) \\
\end{array}$ & $\begin{array}{l}-0.08^{*} \\
(0.01) \\
\end{array}$ & $\begin{array}{c}-0.08^{*} \\
(0.01) \\
\end{array}$ & $\begin{array}{c}-0.05^{* * *} \\
(0.01)\end{array}$ & $\begin{array}{c}-0.06^{* * *} \\
(0.02) \\
\end{array}$ & $\begin{array}{c}-0.05^{* *} \\
(0.01)\end{array}$ & $\begin{array}{c}-0.06^{* * *} \\
(0.02)\end{array}$ & $\begin{array}{c}-0.86^{* * * *} \\
(0.09)\end{array}$ & $\begin{array}{c}-0.85^{* * * *} \\
(0.09)\end{array}$ & $\begin{array}{c}-0.81^{* * * *} \\
(0.09)\end{array}$ & $\begin{array}{c}-0.89^{* * * *} \\
(0.10)\end{array}$ \\
\hline Exporter & $\begin{array}{c}0.53^{* * * *} \\
(0.02) \\
\end{array}$ & $\begin{array}{c}0.53 * * * \\
(0.02) \\
\end{array}$ & $\begin{array}{c}0.53 * * * \\
(0.02) \\
\end{array}$ & $\begin{array}{c}0.53 * * * \\
(0.02) \\
\end{array}$ & $\begin{array}{c}0.24 * * * \\
(0.02) \\
\end{array}$ & $\begin{array}{c}0.24 * * * \\
(0.02) \\
\end{array}$ & $\begin{array}{c}0.24 * * * \\
(0.02) \\
\end{array}$ & $\begin{array}{c}0.24 * * * \\
(0.04) \\
\end{array}$ & $\begin{array}{c}3.50 * * * \\
(0.15) \\
\end{array}$ & $\begin{array}{c}3.42 * * * \\
(0.15) \\
\end{array}$ & $\begin{array}{c}3.43 * * * \\
(0.15) \\
\end{array}$ & $\begin{array}{c}3.45^{* * *} * \\
(0.15) \\
\end{array}$ \\
\hline Legal status dummies & Yes & Yes & Yes & Yes & Yes & Yes & Yes & Yes & Yes & Yes & Yes & Yes \\
\hline Industry, survey wave and the UK region dummies & Yes & Yes & Yes & Yes & Yes & Yes & Yes & Yes & Yes & Yes & Yes & Yes \\
\hline Constant & $\begin{array}{c}-1.05 * * * * \\
(0.13)\end{array}$ & $\begin{array}{c}-1.05^{* * *} * \\
(0.13)\end{array}$ & $\begin{array}{c}-1.05^{* * * *} \\
(0.13)\end{array}$ & $\begin{array}{c}-1.05^{* * * *} \\
(0.13)\end{array}$ & $\begin{array}{c}-1.73 * * * * \\
(0.17)\end{array}$ & $\begin{array}{c}-1.73 * * * \\
(0.17) \\
\end{array}$ & $\begin{array}{c}-1.73 * * * \\
(0.17) \\
\end{array}$ & $\begin{array}{c}-1.73 * * * \\
(0.17)\end{array}$ & $\begin{array}{c}-14.09 * * * * \\
(1.61) \\
\end{array}$ & $\begin{array}{c}-15.66 * * * * \\
(1.71) \\
\end{array}$ & $\begin{array}{c}-16.01 * * * * \\
(1.71) \\
\end{array}$ & $\begin{array}{c}-15.60^{* * * *} \\
(1.79)\end{array}$ \\
\hline Sigma (e) & & & & & & & & & $\begin{array}{c}47.70 \text { *** } \\
(1.07) \\
\end{array}$ & $\begin{array}{c}47.70 * * * \\
(1.07)\end{array}$ & $\begin{array}{c}47.70 * * * * \\
(1.07)\end{array}$ & $\begin{array}{c}47.70^{* * * *} \\
(1.07) \\
\end{array}$ \\
\hline chi2 & 9134.45 & 4343.05 & 9117.82 & 4350.22 & 9076.55 & 4353.44 & 9086.66 & 4357.09 & 7129.02 & 7136.33 & 7092.09 & 7190.66 \\
\hline Preudo R2 & 0.32 & 0.23 & 0.31 & 0.24 & 0.30 & 0.24 & 0.31 & 0.25 & 0.14 & 0.16 & 0.15 & 0.14 \\
\hline
\end{tabular}

Note: standard errors robust for hereroskedastisity are in parenthesis. Reference groups: small firm (10-49 FTEs); legal ownership (listed company); UK region (North East); survey wave (2002-2004). Industry (1 digit SIC), UK region and year fixed effects were suppressed to save space. Significance level: * $p<0.05 ;{ }^{* *} p<0.01 ;{ }^{* * *} p<0.001 "$

Number of observations 19510. Uncensored observations for Tobit estimation (new product sales $>0$ ) $=4960$

Source: BSD - Business Register (2002-2014) and UKIS - UK Innovation Survey (2002-2014). 
Figure 1: Predicted values of new product development by the firm (vertical axis) for external knowledge collaboration with multiple partner types (horizontal axis) and across four geographical dimensions (KIS vs. non-KIS).
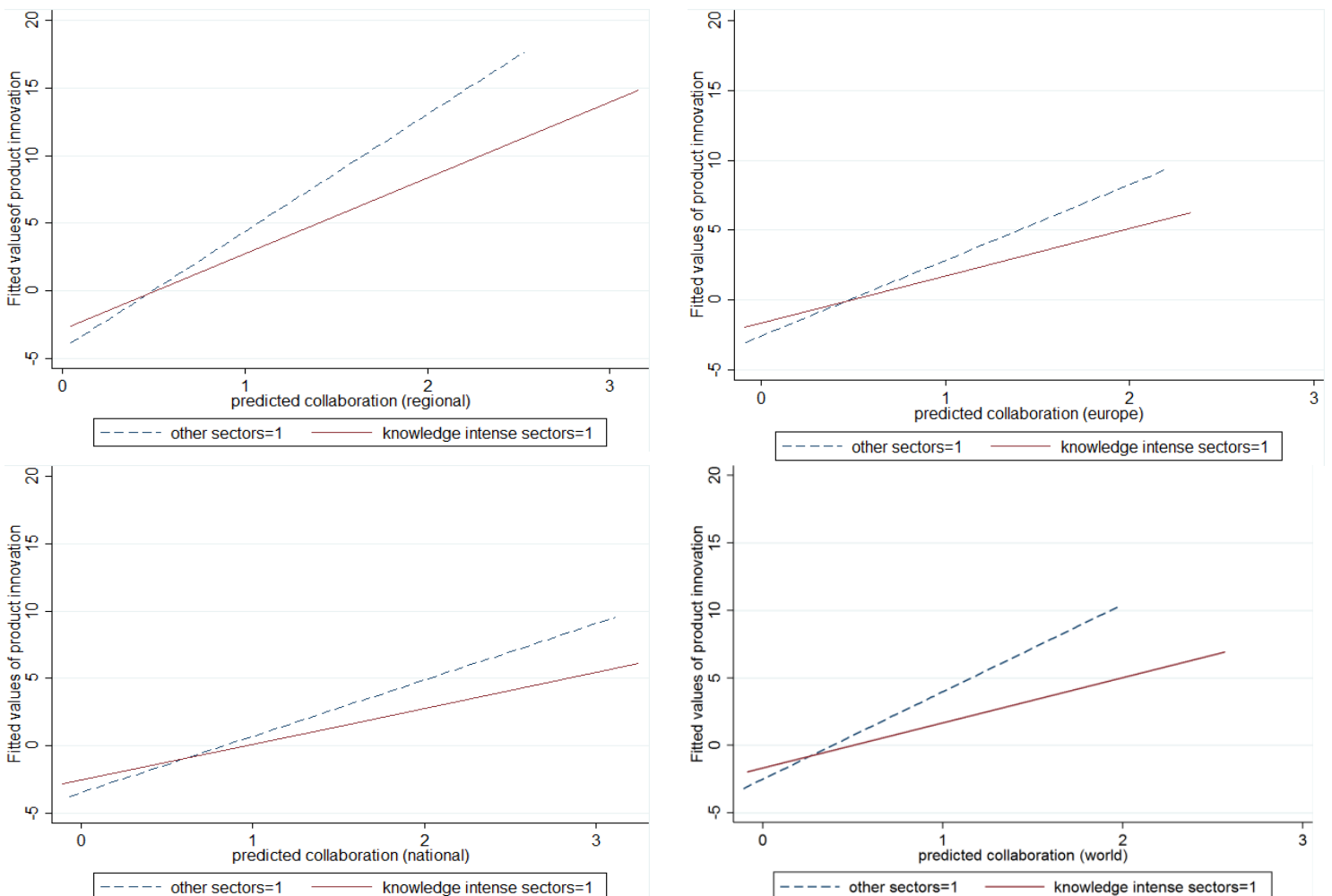

Note: Estimation method: IV Probit with the predicted values of collaboration in the first stage IV regression. Geographical dimensions from top left: regional, national, Europe and international collaboration partners.

Note: Calculation based on Table 6 (columns 1-4). Number of obs. $=19510$

Source: BSD - Business Register (2002-2014) and UKIS - UK Innovation Survey (2002-2014). 


\section{Appendix}

Table A1: Knowledge production function (first-stage): Tobit estimation

\begin{tabular}{|c|c|c|c|c|}
\hline Specification & (2) & (4) & (6) & (8) \\
\hline Dependent variable & $\begin{array}{c}\text { Collaboration } \\
\text { intensity } \\
\text { regional } \\
\end{array}$ & $\begin{array}{c}\text { Collaboration } \\
\text { intensity } \\
\text { national } \\
\end{array}$ & $\begin{array}{c}\text { Collaboration } \\
\text { intensity } \\
\text { Europe } \\
\end{array}$ & $\begin{array}{c}\text { Collaboration } \\
\text { intensity } \\
\text { World } \\
\end{array}$ \\
\hline Method & Tobit & Tobit & Tobit & Tobit \\
\hline \multicolumn{5}{|c|}{ Exclusion restrictions } \\
\hline Enterprise group $\pi_{1}$ & $\begin{array}{l}0.13 * \\
(0.07)\end{array}$ & $\begin{array}{c}0.16 * * * \\
(0.07)\end{array}$ & $\begin{array}{l}0.14 * \\
(0.08)\end{array}$ & $\begin{array}{l}0.20 * \\
(0.10)\end{array}$ \\
\hline External relations $\quad \pi_{2}$ & $\begin{array}{c}1.53 * * * \\
(0.07)\end{array}$ & $\begin{array}{c}1.61 * * * \\
(0.06)\end{array}$ & $\begin{array}{c}1.06 * * * \\
(0.07)\end{array}$ & $\begin{array}{c}1.06 * * * \\
(0.08)\end{array}$ \\
\hline \multicolumn{5}{|c|}{ Other controls } \\
\hline $\mathrm{R} \& \mathrm{D}$ intensity & $\begin{array}{c}3.41 * * * * \\
(0.57) \\
\end{array}$ & $\begin{array}{c}4.30^{* * * *} \\
(0.50)\end{array}$ & $\begin{array}{c}4.86^{* * * *} \\
(0.47) \\
\end{array}$ & $\begin{array}{c}5.43 * * * \\
(0.51)\end{array}$ \\
\hline Medium & $\begin{array}{c}0.06 \\
(0.09)\end{array}$ & $\begin{array}{l}0.13^{*} \\
(0.07)\end{array}$ & $\begin{array}{l}-0.13 \\
(0.10)\end{array}$ & $\begin{array}{l}-0.13 \\
(0.11)\end{array}$ \\
\hline Large & $\begin{array}{l}0.20^{*} \\
(0.10)\end{array}$ & $\begin{array}{c}0.73 * * * \\
(0.10) \\
\end{array}$ & $\begin{array}{c}0.71 \text { **** } \\
(0.11)\end{array}$ & $\begin{array}{c}0.83 * * * \\
(0.13) \\
\end{array}$ \\
\hline Exploration & $\begin{array}{l}-0.09 \\
(0.08)\end{array}$ & $\begin{array}{c}0.03 \\
(0.07)\end{array}$ & $\begin{array}{c}0.34 * * * * \\
(0.07)\end{array}$ & $\begin{array}{c}0.25 * * \\
(0.09)\end{array}$ \\
\hline Hampering factor: cost of innovation & $\begin{array}{c}0.92 * * * \\
(0.08)\end{array}$ & $\begin{array}{c}0.75 * * * \\
(0.07)\end{array}$ & $\begin{array}{c}0.58 * * * \\
(0.07)\end{array}$ & $\begin{array}{c}0.44 * * * \\
(0.08)\end{array}$ \\
\hline Hampering factor: knowledge on market & $\begin{array}{c}0.12 \\
(0.10)\end{array}$ & $\begin{array}{c}0.22 * * \\
(0.09)\end{array}$ & $\begin{array}{c}0.03 \\
(0.10)\end{array}$ & $\begin{array}{c}0.16 \\
(0.11)\end{array}$ \\
\hline Hampering factor: other & $\begin{array}{c}0.11 \\
(0.09) \\
\end{array}$ & $\begin{array}{c}-0.12 \\
(0.08) \\
\end{array}$ & $\begin{array}{c}0.09 \\
(0.09) \\
\end{array}$ & $\begin{array}{c}0.04 \\
(0.10) \\
\end{array}$ \\
\hline Foreign & $\begin{array}{l}-0.08 \\
(0.09)\end{array}$ & $\begin{array}{c}0.41 * * * \\
(0.08)\end{array}$ & $\begin{array}{c}0.52 * * * * \\
(0.09)\end{array}$ & $\begin{array}{c}0.51 * * * \\
(0.10)\end{array}$ \\
\hline Age of firm & $\begin{array}{l}-011 * * \\
(0.04)\end{array}$ & $\begin{array}{c}-0.09 * * \\
(0.04)\end{array}$ & $\begin{array}{l}-0.04 \\
(0.05)\end{array}$ & $\begin{array}{l}-0.11^{*} \\
(0.05)\end{array}$ \\
\hline Scientist & $\begin{array}{c}0.01 * * * \\
(0.00)\end{array}$ & $\begin{array}{c}0.02 * * \\
(0.00)\end{array}$ & $\begin{array}{c}0.02 * * * \\
(0.00)\end{array}$ & $\begin{array}{c}0.03 * * * \\
(0.00)\end{array}$ \\
\hline Exporter & $\begin{array}{c}0.47 * * * \\
(0.08)\end{array}$ & $\begin{array}{c}1.11^{* * * *} \\
(0.07)\end{array}$ & $\begin{array}{c}2.51^{* * * *} \\
(0.09) \\
\end{array}$ & $\begin{array}{c}2.55^{* * * *} \\
(0.10) \\
\end{array}$ \\
\hline Legal status dummies & Yes & Yes & Yes & Yes \\
\hline Industry and time dummies & Yes & Yes & Yes & Yes \\
\hline Constant & $\begin{array}{c}-6.51 * * * \\
(0.51) \\
\end{array}$ & $\begin{array}{c}-6.20 * * * \\
(0.43) \\
\end{array}$ & $\begin{array}{c}-7.91 * * * \\
(0.51) \\
\end{array}$ & $\begin{array}{c}-9.04 * * * \\
(0.63) \\
\end{array}$ \\
\hline Left censored obs. & 16190 & 15207 & 17359 & 17648 \\
\hline Number of observations & 19510 & 19510 & 19510 & 19510 \\
\hline Log-likelihood & -19058.09 & -22753.00 & -11149.03 & -9977.17 \\
\hline Chi2 & 1887.34 & 3862.75 & 2228.24 & 1945.11 \\
\hline$\pi_{1=} \pi_{2}=0($ Chi2, p-value $)$ & $\begin{array}{c}445.21 \\
(\mathrm{p}<0.001)\end{array}$ & $\begin{array}{c}630.80 \\
(\mathrm{p}<0.001)\end{array}$ & $\begin{array}{c}253.72 \\
(\mathrm{p}<0.001)\end{array}$ & $\begin{array}{c}201.20 \\
(\mathrm{p}<0.001)\end{array}$ \\
\hline Rho (fraction of variance of the overall error ui). & 0.32 & 0.29 & 0.37 & 0.38 \\
\hline
\end{tabular}

Note: $\mathrm{RE}$ - random effects panel data estimation; standard errors robust for hereroskedastisity are in parenthesis.

Reference groups: small firm (10-49 FTEs); legal ownership (listed company); survey wave (2002-2004). Industry (1 digit SIC) and year

fixed effects as well as legal ownership status dummies are suppressed to save space. Significance level: ${ }^{*} p<0.05 ;{ }^{* *} \mathrm{p}<0.01 ;{ }^{* * *} \mathrm{p}<0.001{ }^{*}$ Source: BSD - Business Register (2002-2014) and UKIS - UK Innovation Survey (2002-2014). 
Table A2. Sample selection correction bias: outcome equations for each dependent variable.

\begin{tabular}{|c|c|c|c|c|c|c|}
\hline Specification & (1) & (2) & (3) & (4) & (5) & (6) \\
\hline Dependent variable & \multicolumn{2}{|c|}{ Product innovation in-house } & \multicolumn{2}{|c|}{$\begin{array}{c}\text { Product innovation co- } \\
\text { creation }\end{array}$} & \multicolumn{2}{|c|}{$\begin{array}{l}\text { Product innovation sales } \\
\text { (in logs) external }\end{array}$} \\
\hline Method & Probit & Heckman & Probit & Heckman & Tobit & Heckman \\
\hline R\&D intensity & $\begin{array}{c}3.06 * * * \\
(0.36)\end{array}$ & $\begin{array}{l}0.81 * * * \\
(0.05)\end{array}$ & $\begin{array}{c}0.02 \\
(0.24)\end{array}$ & $\begin{array}{c}0.02 \\
(0.04)\end{array}$ & $\begin{array}{c}8.84 * * * \\
(1.30)\end{array}$ & $\begin{array}{c}3.02 * * * \\
(0.40)\end{array}$ \\
\hline Medium & $\begin{array}{c}0.01 \\
(0.02)\end{array}$ & $\begin{array}{c}0.02 \\
(0.02)\end{array}$ & $\begin{array}{c}0.02 \\
(0.03)\end{array}$ & $\begin{array}{c}0.02 \\
(0.03)\end{array}$ & $\begin{array}{l}0.06 \\
(0.16)\end{array}$ & $\begin{array}{c}0.06 \\
(0.16)\end{array}$ \\
\hline Large & $\begin{array}{l}0.08 * * * \\
(0.03)\end{array}$ & $\begin{array}{l}0.03 * * \\
(0.00)\end{array}$ & $\begin{array}{c}0.04 \\
(0.03)\end{array}$ & $\begin{array}{c}0.07 \\
(0.03)\end{array}$ & $\begin{array}{c}1.10 * * * \\
(0.18)\end{array}$ & $\begin{array}{l}0.69^{* * *} \\
(0.04)\end{array}$ \\
\hline Exploration & $\begin{array}{c}0.37 * * * \\
(0.02)\end{array}$ & $\begin{array}{c}0.12 * * * \\
(0.00)\end{array}$ & $\begin{array}{c}0.20^{* * * *} \\
(0.02)\end{array}$ & $\begin{array}{l}0.04 * * \\
(0.00)\end{array}$ & $\begin{array}{l}2.67 * * * \\
(0.17)\end{array}$ & $\begin{array}{c}0.76^{* * *} \\
(0.03)\end{array}$ \\
\hline Hampering factor: cost of innovation & $\begin{array}{c}0.07 * * * * \\
(0.02)\end{array}$ & $\begin{array}{c}0.04 * * * \\
(0.00)\end{array}$ & $\begin{array}{c}0.07 * * * \\
(0.03)\end{array}$ & $\begin{array}{c}0.04 * * * \\
(0.00)\end{array}$ & $\begin{array}{c}1.07 * * * \\
(0.16)\end{array}$ & $\begin{array}{c}0.30 * * * \\
(0.03)\end{array}$ \\
\hline Hampering factor: knowledge on market & $\begin{array}{c}-0.37 * * * \\
(0.03)\end{array}$ & $\begin{array}{c}-0.02 * * * * \\
(0.00)\end{array}$ & $\begin{array}{c}-0.36^{* * * *} \\
(0.01)\end{array}$ & $\begin{array}{c}-0.01 * * \\
(0.00)\end{array}$ & $\begin{array}{c}-1.72 * * \\
(0.16)\end{array}$ & $\begin{array}{c}-0.30^{* * *} \\
(0.03)\end{array}$ \\
\hline Hampering factor: other & $\begin{array}{c}0.04 \\
(0.03)\end{array}$ & $\begin{array}{c}0.04 \\
(0.03)\end{array}$ & $\begin{array}{c}0.03 \\
(0.03) \\
\end{array}$ & $\begin{array}{c}0.03 \\
(0.03) \\
\end{array}$ & $\begin{array}{l}-0.06 \\
(0.18) \\
\end{array}$ & $\begin{array}{l}-0.04 \\
(0.18) \\
\end{array}$ \\
\hline Foreign & $\begin{array}{c}0.01 \\
(0.02)\end{array}$ & $\begin{array}{l}-0.01 \\
(0.01)\end{array}$ & $\begin{array}{l}0.05^{*} \\
(0.02)\end{array}$ & $\begin{array}{l}0.01 * * \\
(0.00)\end{array}$ & $\begin{array}{l}0.23 * * \\
(0.10)\end{array}$ & $\begin{array}{l}0.13 * * \\
(0.04)\end{array}$ \\
\hline Age of firm & $\begin{array}{c}-0.05 * * * \\
(0.01)\end{array}$ & $\begin{array}{c}-0.01 * * * \\
(0.00)\end{array}$ & $\begin{array}{c}-0.04 * * \\
(0.01)\end{array}$ & $\begin{array}{c}-0.01^{* *} \\
(0.00)\end{array}$ & $\begin{array}{c}-0.38 * * * \\
(0.08)\end{array}$ & $\begin{array}{c}-0.05 * * * \\
(0.00)\end{array}$ \\
\hline Scientist & $\begin{array}{c}0.01 * * * \\
(0.00)\end{array}$ & $\begin{array}{c}0.01 * * * \\
(0.00)\end{array}$ & $\begin{array}{l}-0.01 \\
(0.01)\end{array}$ & $\begin{array}{l}-0.01 \\
(0.01)\end{array}$ & $\begin{array}{l}0.05 * * * \\
(0.00)\end{array}$ & $\begin{array}{c}0.02 * * * \\
(0.00)\end{array}$ \\
\hline Exporter & $\begin{array}{c}0.58^{* * * *} \\
(0.02)\end{array}$ & $\begin{array}{c}0.12 * * * \\
(0.01)\end{array}$ & $\begin{array}{c}0.01 \\
(0.00)\end{array}$ & $\begin{array}{c}0.01 \\
(0.00)\end{array}$ & $\begin{array}{c}0.05 * * * \\
(0.00)\end{array}$ & $\begin{array}{c}0.02^{* * *} \\
(0.01)\end{array}$ \\
\hline $\begin{array}{l}\text { Inverse Mill's ratio from selection equation } \\
\qquad(\lambda)\end{array}$ & & $\begin{array}{c}0.35 \\
(0.21)\end{array}$ & & $\begin{array}{c}0.24 \\
(0.22)\end{array}$ & & $\begin{array}{c}1.76 \\
(1.25)\end{array}$ \\
\hline Constant & $\begin{array}{c}-1.16^{* * * *} \\
(0.12) \\
\end{array}$ & $\begin{array}{c}-0.06^{* *} \\
(0.03) \\
\end{array}$ & $\begin{array}{c}-1.79^{* * * *} \\
(0.15) \\
\end{array}$ & $\begin{array}{l}-0.01 \\
(0.02) \\
\end{array}$ & $\begin{array}{c}-10.10^{* * * *} \\
(0.87) \\
\end{array}$ & $\begin{array}{l}-0.10 \\
(0.07) \\
\end{array}$ \\
\hline Legal status dummies & Yes & Yes & Yes & Yes & Yes & Yes \\
\hline $\begin{array}{c}\text { Industry, survey wave and the UK region } \\
\text { dummies }\end{array}$ & Yes & Yes & Yes & Yes & Yes & Yes \\
\hline Wald chi2 (F-stat) & 5601.01 & 5594.34 & 3222.32 & 1906.04 & 256.11 & 3892.64 \\
\hline Number of observations & & 22073 & & 22073 & & 21770 \\
\hline $\begin{array}{l}\text { Number of observations } \\
\text { (selected for Heckman) }\end{array}$ & 19510 & (19510) & 19510 & (19510) & 19510 & (19510) \\
\hline Rho & & 0.81 & & 0.78 & & 0.69 \\
\hline
\end{tabular}

Note: standard errors robust for hereroskedastisity are in parenthesis. Reference groups: small firm (10-49 FTEs); legal ownership (listed company); UK region (North East); survey wave (2002-2004). Industry (1 digit SIC), UK region and year fixed effects were suppressed to save space. Significance level: * $\mathrm{p}<0.05 ; * * \mathrm{p}<0.01 ; * * * \mathrm{p}<0.001 "$.

Variables for selection equation in Heckman: Number of active plant units, in logs, Impediment to innovation - finance availability, regulatory requirements.

Endogenous variables of collaboration are not included in the sample selection test to avoid endogeneity in the model. Number of observations 19510. Uncensored observations for Tobit estimation (column 5 and 6) (new product sales $>0)=$ 4960.

Source: BSD - Business Register (2002-2014) and UKIS - UK Innovation Survey (2002-2014). 
Table A3. Two stage post-estimation analysis: random effect (RE) estimation of model (4) using predicted residuals of product innovation in-house, product innovation external and innovation sales from second stage estimation (model 2).

\begin{tabular}{|c|c|c|c|c|c|c|c|c|c|c|c|c|}
\hline & (1) & (2) & (3) & (4) & (5) & (6) & (7) & (8) & (9) & (10) & (11) & (12) \\
\hline $\begin{array}{l}\text { Dependent } \\
\text { variable }\end{array}$ & \multicolumn{4}{|c|}{$\begin{array}{c}\text { Product innovation in-house } \\
\text { residual } y_{i}-\widehat{y}_{i} \text { across } \\
\text { four partner regions }\end{array}$} & \multicolumn{4}{|c|}{$\begin{array}{c}\text { Product innovation external residual } \\
y_{i}-\widehat{y}_{i} \text { across four partner regions }\end{array}$} & \multicolumn{4}{|c|}{$\begin{array}{l}\text { New product sales residual } y_{i}-\widehat{y}_{i} \\
\text { across four partner regions }\end{array}$} \\
\hline $\begin{array}{l}\text { Equation with the } \\
\text { dimension of } \\
\text { collaboration used } \\
\text { to predict } \widehat{\boldsymbol{y}}_{\boldsymbol{i}}\end{array}$ & 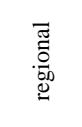 & 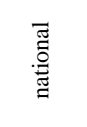 & 苂 & $\frac{\bar{t}}{\bar{D}}$ & 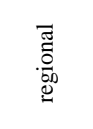 & 胥 & 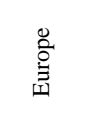 & $\frac{7}{\grave{D}}$ & 丞 & $\stackrel{\overparen{\Xi}}{\stackrel{\Xi}{\Xi}}$ & 蒙 & $\frac{\vec{D}}{\grave{D}}$ \\
\hline $\begin{array}{l}\text { Enterprise } \\
\text { group } \rho_{1}\end{array}$ & $\begin{array}{c}0.01 \\
(0.02)\end{array}$ & $\begin{array}{c}0.01 \\
(0.01)\end{array}$ & $\begin{array}{c}0.01 \\
(0.01)\end{array}$ & $\begin{array}{c}0.02 \\
(0.02)\end{array}$ & $\begin{array}{c}0.03 \\
(0.03)\end{array}$ & $\begin{array}{c}0.03 \\
(0.04)\end{array}$ & $\begin{array}{c}0.03 \\
(0.02)\end{array}$ & $\begin{array}{c}0.03 \\
(0.05)\end{array}$ & $\begin{array}{c}0.05 \\
(0.12)\end{array}$ & $\begin{array}{l}0.05 \\
(0.11)\end{array}$ & $\begin{array}{c}0.05 \\
(0.13)\end{array}$ & $\begin{array}{c}0.04 \\
(0.13)\end{array}$ \\
\hline $\begin{array}{l}\text { External } \\
\text { relations } \quad \rho_{2}\end{array}$ & $\begin{array}{c}0.38 \\
(0.21)\end{array}$ & $\begin{array}{c}0.38 \\
(0.22) \\
\end{array}$ & $\begin{array}{c}0.36 \\
(0.22) \\
\end{array}$ & $\begin{array}{c}0.39 \\
(0.22) \\
\end{array}$ & $\begin{array}{c}0.27 \\
(0.15) \\
\end{array}$ & $\begin{array}{c}0.26 \\
(0.15) \\
\end{array}$ & $\begin{array}{c}0.27 \\
(0.17) \\
\end{array}$ & $\begin{array}{c}0.29 \\
(0.21) \\
\end{array}$ & $\begin{array}{c}2.69 \\
(1.37) \\
\end{array}$ & $\begin{array}{c}2.62 \\
(1.26) \\
\end{array}$ & $\begin{array}{l}2.78^{*} \\
(1.17) \\
\end{array}$ & $\begin{array}{l}2.79 * \\
(1.19)\end{array}$ \\
\hline \multicolumn{13}{|c|}{ Control variables } \\
\hline $\begin{array}{c}\text { Legal status } \\
\text { controls }\end{array}$ & Yes & Yes & Yes & Yes & Yes & Yes & Yes & Yes & Yes & Yes & Yes & Yes \\
\hline $\begin{array}{l}\text { Industry, and wave } \\
\text { controls }\end{array}$ & Yes & Yes & Yes & Yes & Yes & Yes & Yes & Yes & Yes & Yes & Yes & Yes \\
\hline Region controls & Yes & Yes & Yes & Yes & Yes & Yes & Yes & Yes & Yes & Yes & Yes & Yes \\
\hline Constant & $\begin{array}{c}1.35^{* *} \\
* \\
(0.36) \\
\end{array}$ & $\begin{array}{c}1.33 * * \\
* \\
(0.33) \\
\end{array}$ & $\begin{array}{c}1.31 * * \\
* \\
(0.32) \\
\end{array}$ & $\begin{array}{c}1.27 * * \\
* \\
(0.26) \\
\end{array}$ & $\begin{array}{c}1.84 * * * \\
(0.27)\end{array}$ & $\begin{array}{c}1.86^{* * *} \\
* \\
(0.27) \\
\end{array}$ & $\begin{array}{c}1.89 * * \\
* \\
(0.37) \\
\end{array}$ & $\begin{array}{c}1.85^{* *} \\
* \\
(0.34) \\
\end{array}$ & $\begin{array}{c}9.85^{* *} \\
* \\
(2.61) \\
\end{array}$ & $\begin{array}{c}9.80 * * \\
* \\
(3.01) \\
\end{array}$ & $\begin{array}{c}9.72 * * \\
* \\
(2.71) \\
\end{array}$ & $\begin{array}{c}9.91 * * \\
* \\
(2.70) \\
\end{array}$ \\
\hline Chi2 & 40,177 & 40,320 & 40,980 & 41,452 & 46,013 & 45,822 & 46187 & 45,738 & 24,392 & 24,120 & 24,104 & 23,945 \\
\hline
\end{tabular}

Note: standard errors robust for hereroskedastisity are in parenthesis. Reference groups: Legal status (listed company); UK region (North East); survey wave (2002-2004). Industry (1 digit SIC), UK region and year fixed effects were suppressed to save space. Significance level: $* \mathrm{p}<0.05 ; * * \mathrm{p}<0.01 ; * * * \mathrm{p}<0.001 "$.

Coefficients $\rho_{2}$ (new methods of collaboration) are weakly significant ( $\left.\mathrm{p}<0.10\right)$ in model 3 when innovation sales residuals is used as dependent variable. Number of observations 19510.

Source: BSD - Business Register (2002-2014) and UKIS - UK Innovation Survey (2002-2014). 
Table A4. Knowledge production function

\begin{tabular}{|c|c|c|c|c|c|c|c|c|c|}
\hline & (1) & (2) & (3) & (4) & (5) & (6) & (7) & (8) & (9) \\
\hline Dependent variable & \multicolumn{3}{|c|}{ Product innovation in-house } & \multicolumn{3}{|c|}{ Product innovation co-creation } & \multicolumn{3}{|c|}{$\begin{array}{l}\text { Product innovation sales } \\
\text { (in logs) external }\end{array}$} \\
\hline Method & \multicolumn{3}{|c|}{ Probit } & \multicolumn{3}{|c|}{ Probit } & \multicolumn{3}{|c|}{ Tobit } \\
\hline $\begin{array}{l}\text { Product innovation } \\
\text { co-creation }\end{array}$ & & $\begin{array}{c}-0.44 * * * \\
(0.03)\end{array}$ & $\begin{array}{c}-0.41 * * * \\
(0.03)\end{array}$ & & & & & $\begin{array}{c}1.23^{* * *} \\
(0.04)\end{array}$ & $\begin{array}{c}1.24 * * * \\
(0.05)\end{array}$ \\
\hline $\begin{array}{c}\text { Product innovation } \\
\text { co-creation X Standardized } \\
\text { R\&D intensity }\end{array}$ & & & $\begin{array}{c}-0.20^{* * * *} \\
(0.03)\end{array}$ & & & & & & $\begin{array}{c}0.10 \\
(0.06)\end{array}$ \\
\hline $\begin{array}{c}\text { Product innovation } \\
\text { co-creation X Standardized } \\
\text { Scientists }\end{array}$ & & & $\begin{array}{c}-0.08 * * * \\
(0.02)\end{array}$ & & & & & & $\begin{array}{l}0.05^{*} \\
(0.02)\end{array}$ \\
\hline Product innovation in-house & & & & & $\begin{array}{c}-0.48 * * * \\
(0.03) \\
\end{array}$ & $\begin{array}{c}-0.44^{* * * *} \\
(0.03) \\
\end{array}$ & & $\begin{array}{c}2.61^{* * * *} \\
(0.04)\end{array}$ & $\begin{array}{c}2.58 * * * \\
(0.03)\end{array}$ \\
\hline $\begin{array}{l}\text { Product innovation in-house } \\
\text { X Standardized R\&D } \\
\text { intensity }\end{array}$ & & & & & & $\begin{array}{c}-0.16^{* * * *} \\
(0.03)\end{array}$ & & & $\begin{array}{c}0.19 \\
(0.09)\end{array}$ \\
\hline $\begin{array}{l}\text { Product innovation in-house } \\
\text { X Standardized Scientists } \\
\end{array}$ & & & & & & $\begin{array}{c}-0.14 * * * * \\
(0.02) \\
\end{array}$ & & & $\begin{array}{c}0.20^{* * * *} \\
(0.03) \\
\end{array}$ \\
\hline $\begin{array}{c}\text { Knowledge intense sectors } \\
\text { (KIS) }\end{array}$ & $\begin{array}{l}0.07 * \\
(0.03)\end{array}$ & $\begin{array}{l}0.07^{*} \\
(0.02)\end{array}$ & $\begin{array}{l}0.07^{*} \\
(0.03)\end{array}$ & $\begin{array}{c}0.04 \\
(0.03)\end{array}$ & $\begin{array}{c}0.03 \\
(0.03)\end{array}$ & $\begin{array}{c}0.03 \\
(0.03)\end{array}$ & $\begin{array}{l}0.11 * \\
(0.05)\end{array}$ & $\begin{array}{c}0.05 \\
(0.04)\end{array}$ & $\begin{array}{c}0.05 \\
(0.04)\end{array}$ \\
\hline Standardized R\&D intensity & $\begin{array}{c}0.17 * * * \\
(0.01) \\
\end{array}$ & $\begin{array}{c}0.18^{* * * *} \\
(0.01) \\
\end{array}$ & $\begin{array}{c}0.22 * * * \\
(0.02)\end{array}$ & $\begin{array}{c}0.01 \\
(0.02) \\
\end{array}$ & $\begin{array}{c}0.02 \\
(0.02) \\
\end{array}$ & $\begin{array}{c}0.12 * * * \\
(0.02) \\
\end{array}$ & $\begin{array}{c}0.19^{* * * *} \\
(0.02) \\
\end{array}$ & $\begin{array}{c}0.07 * * * \\
(0.01)\end{array}$ & $\begin{array}{c}0.20^{* * *} \\
(0.03) \\
\end{array}$ \\
\hline Standardized Scientist & $\begin{array}{c}0.13^{* * *} \\
(0.01)\end{array}$ & $\begin{array}{c}0.14 * * * \\
(0.01)\end{array}$ & $\begin{array}{c}0.15^{* * * *} \\
(0.01)\end{array}$ & $\begin{array}{c}0.01 \\
(0.02)\end{array}$ & $\begin{array}{c}0.03 \\
(0.01)\end{array}$ & $\begin{array}{c}0.10 * * * \\
(0.02)\end{array}$ & $\begin{array}{c}0.32 * * * \\
(0.02)\end{array}$ & $\begin{array}{c}0.18 * * * \\
(0.01)\end{array}$ & $\begin{array}{c}0.10^{* * *} \\
(0.02)\end{array}$ \\
\hline Medium & $\begin{array}{c}0.02 \\
(0.02)\end{array}$ & $\begin{array}{c}0.02 \\
(0.02)\end{array}$ & $\begin{array}{c}0.01 \\
(0.02)\end{array}$ & $\begin{array}{c}0.01 \\
(0.02)\end{array}$ & $\begin{array}{c}0.01 \\
(0.03)\end{array}$ & $\begin{array}{c}0.01 \\
(0.03)\end{array}$ & $\begin{array}{c}0.06 \\
(0.03)\end{array}$ & $\begin{array}{c}0.05 \\
(0.03)\end{array}$ & $\begin{array}{c}0.05 \\
(0.03)\end{array}$ \\
\hline Large & $\begin{array}{c}0.08^{* * * *} \\
(0.02)\end{array}$ & $\begin{array}{c}0.08 * * * \\
(0.03)\end{array}$ & $\begin{array}{c}0.08 * * \\
(0.02)\end{array}$ & $\begin{array}{c}0.02 \\
(0.03)\end{array}$ & $\begin{array}{c}0.02 \\
(0.03)\end{array}$ & $\begin{array}{c}0.01 \\
(0.03)\end{array}$ & $\begin{array}{c}0.57^{* * * *} \\
(0.04)\end{array}$ & $\begin{array}{c}0.52 * * * \\
(0.04)\end{array}$ & $\begin{array}{c}0.52 * * * \\
(0.05)\end{array}$ \\
\hline Exploration & $\begin{array}{c}0.37 * * * \\
(0.02)\end{array}$ & $\begin{array}{c}0.38 * * * \\
(0.02)\end{array}$ & $\begin{array}{c}0.39 * * * \\
(0.02)\end{array}$ & $\begin{array}{c}0.20^{* * * *} \\
(0.02)\end{array}$ & $\begin{array}{c}0.24 * * * \\
(0.03)\end{array}$ & $\begin{array}{c}0.24 * * * \\
(0.03)\end{array}$ & $\begin{array}{c}0.61^{* * * *} \\
(0.03)\end{array}$ & $\begin{array}{c}0.34 * * * \\
(0.03)\end{array}$ & $\begin{array}{c}0.34 * * * \\
(0.03)\end{array}$ \\
\hline $\begin{array}{c}\text { Hampering factor: cost of } \\
\text { innovation }\end{array}$ & $\begin{array}{c}0.07 * * * \\
(0.02)\end{array}$ & $\begin{array}{c}0.07 * * * \\
(0.02)\end{array}$ & $\begin{array}{c}0.07 * * \\
(0.03)\end{array}$ & $\begin{array}{c}0.07 * * * \\
(0.02) \\
\end{array}$ & $\begin{array}{c}0.07^{* * * *} \\
(0.02) \\
\end{array}$ & $\begin{array}{l}0.07 * * \\
(0.03) \\
\end{array}$ & $\begin{array}{c}0.23 * * * * \\
(0.03)\end{array}$ & $\begin{array}{c}0.13 * * * \\
(0.03)\end{array}$ & $\begin{array}{c}0.13^{* * * *} \\
(0.03)\end{array}$ \\
\hline $\begin{array}{l}\text { Hampering factor: } \\
\text { knowledge on market }\end{array}$ & $\begin{array}{c}-0.37 * * * \\
(0.03)\end{array}$ & $\begin{array}{c}-0.42 * * * \\
(0.03)\end{array}$ & $\begin{array}{c}-0.42 * * * \\
(0.03)\end{array}$ & $\begin{array}{c}-0.37 * * * \\
(0.03)\end{array}$ & $\begin{array}{c}-0.45 * * * \\
(0.03)\end{array}$ & $\begin{array}{c}-0.44 * * * \\
(0.03)\end{array}$ & $\begin{array}{c}-0.48 * * * \\
(0.04)\end{array}$ & $\begin{array}{c}-0.13 * * \\
(0.04)\end{array}$ & $\begin{array}{c}-0.14 * * \\
(0.04)\end{array}$ \\
\hline Hampering factor: other & $\begin{array}{c}-0.25 * * * \\
(0.03) \\
\end{array}$ & $\begin{array}{c}-0.28 * * * \\
(0.03)\end{array}$ & $\begin{array}{c}-0.27 * * * * \\
(0.03) \\
\end{array}$ & $\begin{array}{c}-0.21 * * * \\
(0.03)\end{array}$ & $\begin{array}{c}-0.26 * * * \\
(0.04) \\
\end{array}$ & $\begin{array}{c}-0.25 * * * \\
(0.03) \\
\end{array}$ & $\begin{array}{c}-0.43 * * * \\
(0.04) \\
\end{array}$ & $\begin{array}{c}-0.20 * * * \\
(0.04) \\
\end{array}$ & $\begin{array}{c}-0.21 * * * * \\
(0.04) \\
\end{array}$ \\
\hline Foreign & $\begin{array}{c}0.01 \\
(0.02)\end{array}$ & $\begin{array}{c}0.01 \\
(0.02)\end{array}$ & $\begin{array}{c}0.00 \\
(0.01)\end{array}$ & $\begin{array}{c}0.05 \\
(0.02)\end{array}$ & $\begin{array}{l}0.06^{*} \\
(0.02)\end{array}$ & $\begin{array}{l}0.05^{* *} \\
(0.01)\end{array}$ & $\begin{array}{l}0.10^{* *} \\
(0.03)\end{array}$ & $\begin{array}{l}0.07 * \\
(0.03)\end{array}$ & $\begin{array}{l}0.07 * \\
(0.03)\end{array}$ \\
\hline Age of firm & $\begin{array}{l}-0.05^{*} \\
(0.01) \\
\end{array}$ & $\begin{array}{l}-0.06^{*} \\
(0.01) \\
\end{array}$ & $\begin{array}{l}-0.06^{*} \\
(0.01) \\
\end{array}$ & $\begin{array}{l}-0.04^{*} \\
(0.01) \\
\end{array}$ & $\begin{array}{c}-0.05 * * \\
(0.01) \\
\end{array}$ & $\begin{array}{c}-0.05^{* *} \\
(0.01) \\
\end{array}$ & $\begin{array}{c}-0.07 * * * \\
(0.02)\end{array}$ & $\begin{array}{c}-0.03^{*} \\
(0.01) \\
\end{array}$ & $\begin{array}{c}-0.04 * * \\
(0.01) \\
\end{array}$ \\
\hline Exporter & $\begin{array}{c}0.57 * * * \\
(0.02) \\
\end{array}$ & $\begin{array}{c}0.60 * * * \\
(0.02)\end{array}$ & $\begin{array}{c}0.60 * * * \\
(0.02)\end{array}$ & $\begin{array}{c}0.31 * * * \\
(0.02)\end{array}$ & $\begin{array}{c}0.39 * * * \\
(0.02)\end{array}$ & $\begin{array}{c}0.38 * * * \\
(0.02)\end{array}$ & $\begin{array}{c}1.03 * * * \\
(0.03)\end{array}$ & $\begin{array}{c}0.52^{* * * *} \\
(0.03)\end{array}$ & $\begin{array}{c}0.52 * * * \\
(0.02)\end{array}$ \\
\hline Legal status dummies & Yes & Yes & Yes & Yes & Yes & Yes & Yes & Yes & Yes \\
\hline $\begin{array}{l}\text { Industry, survey wave and } \\
\text { the UK region dummies }\end{array}$ & Yes & Yes & Yes & Yes & Yes & Yes & Yes & Yes & Yes \\
\hline Constant & $\begin{array}{c}-1.06 * * * \\
(0.13)\end{array}$ & $\begin{array}{c}-1.06^{* * *} \\
(0.13)\end{array}$ & $\begin{array}{c}-1.04 * * * \\
(0.13)\end{array}$ & $\begin{array}{c}-1.70 * * * \\
(0.16)\end{array}$ & $\begin{array}{c}-1.62 * * * \\
(0.15)\end{array}$ & $\begin{array}{c}-1.60^{* * * *} \\
(0.16)\end{array}$ & $\begin{array}{c}-11.09 * * * \\
(1.81)\end{array}$ & $\begin{array}{c}-11.65^{* * *} \\
(1.31)\end{array}$ & $\begin{array}{c}-11.77 * * * \\
(1.39)\end{array}$ \\
\hline Sigma (e) & & & & & & & $\begin{array}{c}5.39 * * * \\
(0.05) \\
\end{array}$ & $\begin{array}{c}4.32 * * * \\
(0.03)\end{array}$ & $\begin{array}{c}4.31^{* * * *} \\
(0.03)\end{array}$ \\
\hline chi2 & 8028.15 & 8231.45 & 8315.55 & 3614.12 & 3866.05 & 4002.04 & 7925.06 & 12629.01 & 12685.52 \\
\hline
\end{tabular}

Note: standard errors robust for hereroskedastisity are in parenthesis. Reference groups: small firm (10-49 FTEs); legal ownership (listed company); UK region (North East); survey wave (2002-2004). Industry (1 digit SIC), UK region and year fixed effects were suppressed to save space. Significance level: * $p<0.05 ;{ }^{* *} p<0.01 ; * *$ p $<0.001 "$.

Number of observations 19510. Uncensored observations for Tobit estimation (new product sales $>0)=4960$.

Source: BSD - Business Register (2002-2014) and UKIS - UK Innovation Survey (2002-2014). 